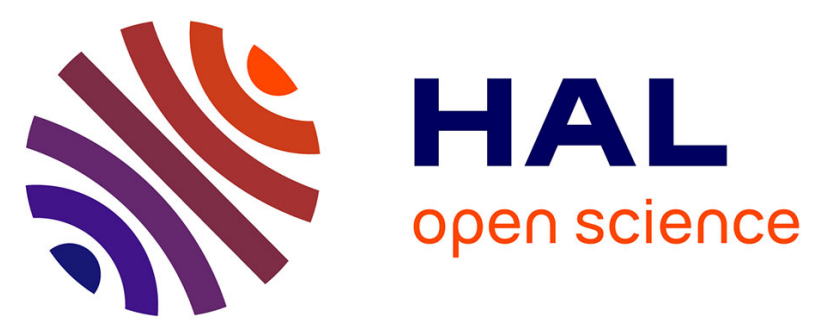

\title{
How does the resuspension of the biofilm alter the functioning of the benthos-pelagos coupled food web of a bare mudflat in Marennes-Oléron Bay (NE Atlantic)?
}

Blanche Saint-Béat, Christine Dupuy, Hélène Agogué, Alexandre Carpentier, Julien Chalumeau, Serena Como, Valérie David, Margot de Crignis, Jean-Claude Duchêne, Camille Fontaine, et al.

\section{To cite this version:}

Blanche Saint-Béat, Christine Dupuy, Hélène Agogué, Alexandre Carpentier, Julien Chalumeau, et al.. How does the resuspension of the biofilm alter the functioning of the benthos-pelagos coupled food web of a bare mudflat in Marennes-Oléron Bay (NE Atlantic)?. Journal of Sea Research (JSR), 2014, 92, pp.144-157. 10.1016/j.seares.2014.02.003 . hal-01097877

\section{HAL Id: hal-01097877 https://hal.science/hal-01097877}

Submitted on 10 Jan 2015

HAL is a multi-disciplinary open access archive for the deposit and dissemination of scientific research documents, whether they are published or not. The documents may come from teaching and research institutions in France or abroad, or from public or private research centers.
L'archive ouverte pluridisciplinaire HAL, est destinée au dépôt et à la diffusion de documents scientifiques de niveau recherche, publiés ou non, émanant des établissements d'enseignement et de recherche français ou étrangers, des laboratoires publics ou privés. 
1 How does the resuspension of the biofilm alter the functioning of the

2 benthos-pelagos coupled food web of a bare mudflat in Marennes-Oléron

$3 \quad$ Bay (NE Atlantic)?

4

5 Blanche Saint-Béat ${ }^{\mathrm{a}^{*}}$, Christine Dupuy ${ }^{\mathrm{a}}$, Hélène Agogué ${ }^{\mathrm{a}}$, Alexandre Carpentier ${ }^{\mathrm{b}}$, Julien 6 Chalumeau $^{\mathrm{a}}$, Serena Como ${ }^{\mathrm{a}}$, Valérie David ${ }^{\mathrm{c}}$, Margot De Crignis ${ }^{\mathrm{a}}$, Jean-Claude Duchêne ${ }^{\mathrm{c}}$, 7 Camille Fontaine ${ }^{\mathrm{a}}$, Eric Feunteun ${ }^{\mathrm{b}}$, Katell Guizien ${ }^{\mathrm{d}}$, Hans Hartmann ${ }^{\mathrm{a}}$, Johann Lavaud ${ }^{\mathrm{a}}$, 8 Sébastien Lefebvre ${ }^{\mathrm{e}}$, Christel Lefrancois ${ }^{\mathrm{a}}$, Clarisse Mallet ${ }^{\mathrm{f}}$, Hélène Montaniéa ${ }^{\mathrm{a}}$, Jean-Luc 9 Mouget $^{\mathrm{g}}$, Francis Orvain ${ }^{\mathrm{h}}$, Pascaline Ory ${ }^{\mathrm{a}}$, Pierre-Yves Pascal ${ }^{\mathrm{i}}$, Gilles Radenac ${ }^{\mathrm{a}}$, Pierre Richard $^{\mathrm{a}}$, Alain Vézina ${ }^{\mathrm{j}}$, Nathalie Niquil ${ }^{\mathrm{a}, \mathrm{h}}$.

${ }^{a}$ Université de la Rochelle-CNRS, UMR 7266, Littoral Environnement et Sociétés (LIENSs),

2 rue Olympe de Gouges 17000 La Rochelle cedex, France

b Station Maritime de Dinard, Museum National d'Histoire Naturelle, 17 avenue George V, BP28, 35801 Dinard, France

c UMR 5805 EPOCU, Station Marine d'Arcachon, Université Bordeaux 1, 2 Rue du

d Laboratoire d'Océanographie Biologique de Banyuls, rue du Fontaulé, BP 44, 66651

e Université de Lille 1/Station Marine de Wimereux, UMR CNRS 8187, Laboratoire 
f CNRS-Université de Clermont-Ferrand II, UMR 6023, Laboratoire Microorganismes:

23 Génome et Environnement, 24 avenue des Landais, 63177 Aubière Cedex, France

g Université du Maine, EA 2663 «Ecophysiologie Marine Intégrée » Laboratoire de Physiologie et Biochimie Végétales, avenue Olivier Messiaen, 72085 Le Mans cedex 9,

26 France

$27{ }^{\mathrm{h}}$ Université de Caen Basse-Normandie, FRE3484 BioMEA CNRS, Esplanade de la Paix, 2814032 Caen cedex, France

29 i Université des Antilles et de la Guyane, UMR 7138 SAE, Pointe-à-Pitre, Guadeloupe

$30 \mathrm{j}$ Bedford Institute of Oceanography, 1 Challenger Drive, P.O. Box 1006, 31 Dartmouth, NS, Canada, B2Y 4A2

32

$33 *$ Corresponding author at Université de la Rochelle-CNRS, UMR 7266, Littoral 34 Environnement et Sociétés (LIENSs), 2 rue Olympe de Gouges 17000 La Rochelle cedex, 35 France

36 tel: +33546458314

37 e-mail address :blanche.saint-beat@univ-lr.fr 


\section{Abstract}

Intertidal mudflats are ecosystems submitted to natural hydrodynamical forcings during each tide. When the offshore water flows at high tide, a proportion of the biofilm produced at low tide can be resuspended in the water column and interact with the pelagic food web. As a consequence, the resuspension creates a link between the benthos and the pelagos, modifying their properties and the stability of the meta-ecosystem they form together. The aim of this study is to describe the consequences of the microbial biofilm resuspension on the pelagic food web, and to investigate the question of the stability of the benthos-pelagos coupling resulting from the biofilm resuspension. Two food webs were considered, corresponding to different hydrodynamical conditions in summer condition: one allowing the biofilm massive resuspension, and one without resuspension, but with particle sedimentation. The MonteCarlo Markov Chain Linear Modelling was used to estimate the unknown flows of the food web. The comparison of the Ecological Network Analysis indices for the two food webs allowed defining their respective differences of structure and functioning. The results showed that the massive resuspension of the microbial biofilm stimulates pelagic primary production and microbial food web via a higher bacterivory. The higher activity of the whole system coupled with both a drop in the specialization of the trophic pathways and a low cycling activity demonstrated that when massive resuspension occurs, the system is disturbed. In contrast, when sedimentation occurs, the food webs show functioning features pointing out to a higher stability of the whole system.

Keywords: intertidal mudflat, biofilm resuspension, stability, meta-ecosystem 


\section{Introduction}

The structure and the functioning of food webs affect the emergent properties and thus the stability of the ecosystem. As a consequence, describing the emergent properties of the ecosystem is a prerequisite for establishing their stability. The literature on the subject is diverse and can lead to controversial interpretations and conclusions. However, some trends can be observed such as equilibrium between two extremes that allows the ecosystem to act like a buffer to external perturbations. For instance, the coexistence of weak and strong interactions is assumed to bring stability to the ecosystem (McCann et al., 1998), or the asymmetry in the ecosystem ensures a higher stability (Rooney et al., 2006), or an ecosystem that presents a balance between Ascendency and redundancy is supposed to be more stable (Ulanowicz, 2003). Moreover, Levin (1999) proposed that a stable ecosystem pattern is composed of subsystems strongly intraconnected but weakly interconnected. At larger scale, this theory is transposable to the concept of the meta-ecosystem defined by Loreau et al. (2003) as a set of ecosystems connected by spatial flows. A set of ecosystems strongly intraconnected weakly interconnected thus form a stable meta-ecosystem. In this study, we propose to consider the benthos and the pelagos as systems connected by spatial flows at high tide to form a stable meta-system. We have used this concept in order to describe and to understand the effects of the benthos-pelagos coupling on the properties of the food webs and its consequences on the stability of the Brouage mudflat meta-system.

As bare intertidal mudflat, Brouage mudflat, is characterized by the development of a microbial biofilm at the surface of the sediments at diurnal low tide. This biofilm is usually mainly composed of brown micro-algae (diatoms) which constitute the microphytobenthos (Cariou-Le Gall and Blanchard, 1995) and prokaryotes, all of them linked by a matrix of extracellular polymeric substances (EPS) (Decho, 2000). The production of the biofilm is integrated to the benthic food web via the deposit feeders, especially Peringia ulvae (Haubois 
et al., 2005; Pascal et al., 2008a; Pascal et al., 2009), via the facultative suspension feeders and via the meiofauna (Pascal et al., 2009; Pascal et al., 2008b; Pascal et al., 2008c). The meio- and macrofauna are not only involved in the regulation of the microphytobenthos biomass via the grazing, but also via the bioturbation and the biostabilisation of the sediment whose effects are coupled with physical factors (tides and swell) (Blanchard et al., 2001).

When the tidal flow arises, the microphytobenthos biomass decreases at the surface of the sediments (Guarini et al., 2000) for two reasons: i) the downward 'migration' of motile diatoms into the sediments (Consalvey et al., 2004; Guarini et al., 2000; Herlory et al., 2004; Ni Longphuirt et al., 2009) and ii) the resuspension of a part of the diatom stock into the water column. The resuspension of the microphytobenthic biofilm is controlled by a complex interaction between physical and biological forcing. The physical resuspension of the microphytobenthos depends on the bed shear stress which is induced by the tidal current and/or the wind-waves (Blanchard et al., 2002; De Jonge and Van Beuselom, 1992). The erodability of the sediment is strongly variable in space and in time (Tolhurst et al., 2006) and depends on biological factor modifying sediment properties such as macrofauna activities and microbial biofilm setting up (Herman et al., 2001; Orvain et al., 2004). The microphytobenthos resuspension also depends on biological factors such as the ageing of the biofilm (Orvain et al., 2004) and the content of exopolysaccharids (EPS) (Orvain et al., present issue). When the microphytobenthic biofilm is in its exponential growth phase, it stabilizes the sediments and counteracts the bioturbation due to macrofauna which favors its resuspension (Orvain et al., 2004). In contrast, when the biofilm reaches its senescent phase, the roughness of the biofilm as well as bacterial biofilm degradation are enhanced and the mat is more easily resuspended (Orvain et al., 2004). The microphytobenthic diatom that are resuspended in the water column are integrated to the pelagic food web and can be ingested by suspension feeders, in the case of the Brouage mudflat especially by Crassostrea gigas, a 
cultivated species (Riera and Richard, 1996) and Cerastoderma edule (Sauriau and Kang, 2000).

In this study new in situ observations and experimentations were taken into account, especially on the resuspension of the biofilm (Orvain et al., present issue) and the consequences on the pelagic food web are evaluated by using a model describing trophic pathways. Erosion experiments allowed to determine the critical shear velocity necessary regarding the resuspension of benthic micro-organisms and resuspension rates (Dupuy et al., present issue). The Lagrangian and Eulerian field surveys followed the future of the resuspended particles in the water column, respectively following the water mass or at a fixed point (Guizien et al., 2013). Moreover grazing experiments and viral lysis experiments (Montanié et al., present issue) were performed in order to determine the effect of resuspension of benthic organisms on the pelagic food web sensu largo (i.e. including virus). These refinements were incorporated in the framework of a trophic-flow model to better unravel the impact of the biofilm resuspension on the food web functioning by deciphering the contribution of each flow in the contribution in the functioning during high-tide phase. At high tide, the rise of the tide and the chemical/physical/biological processes associated with the increase of the water level on the Brouage mudflat create spatial flows linking benthic and pelagic parts. Consequently, it can be considered as a 'meta-ecosystem' defined by Loreau et al., (2003) as a set of ecosystems which are linked by spatial biotic and/or abiotic flows across the ecosystem boundaries. We especially focused on one question: How does the resuspension of the microbial biofilm at high tide modifies the stability of ecosystem in respect to the metaecosystem pattern? We explored this question by comparing the network organization of two distinct food web models representing 2 scenarii of a summer situation. In the first model scenario, the hydrodynamic conditions were extreme and sufficient to induce the resuspension of the microphytobenthos (physical mass erosion, when bed shear stress BSS $>3 \mathrm{~cm} . \mathrm{s}^{-1}$ on 
Brouage mudflat). In this case the velocity of current stays superior to the critical sinking velocity, thus no sedimentation is possible. While in the second case the physical forcing was too weak to induce any resuspension, only limited and extremely low erosion of chla (biological erosion when BSS $<3 \mathrm{~cm} . \mathrm{s}^{-1}$ ) induced by the bioturbation of the macrofauna can be observed (Orvain et al., present issue). Moreover the settling of pelagic particles (organic or not) could occur and the sinking velocity enhanced by the pelletisation (Orvain et al., present issue). The missing flows of the food web (i.e. flows which were not measured in situ) were estimated by the Monte Carlo Markov Chain Linear Inverse Modelling (MCMC-LIM) (Van den Meersche et al., 2009). This mathematical method explores a solution space defined by constraints issued from in situ measurement and values issued from the literature. All solutions proposed by the MCMC-LIM were used to calculate several ecological network analysis (ENA) indices, describing the emergent properties of the ecosystem.

\section{Material and Methods}

\subsection{The study area}

The Brouage intertidal mudflat is located at the French Atlantic coast in the bay of MarennesOléron (figure 1). The bay covers $150 \mathrm{~km}^{2}$ and the Brouage mudflat, at the eastern part of the bay, represents $68 \mathrm{~km}^{2}$ at low tide. The averaged bottom slope is relatively flat $(1: 1000)$ and the tidal area is large (up to $4 \mathrm{~km})$. The sediment consists of silt and clay particles $(95 \%<63$ $\mu \mathrm{m})$ (Pascal et al., 2009). The current speeds in the bay range from 0.2 to $0.6 \mathrm{~m} . \mathrm{s}^{-1}$ and the bed shear stress from 1.5 to 4 Pa (Bassoullet et al., 2000; Le Hir et al., 2000). The zone of interest is located in the middle of the Brouage mudflat and is characterized by a typical ridge and runnel bedform (Gouleau et al., 2000).

\subsection{Inverse modelling}


Two summer food web models were performed: the first one simulated a high-tide situation with massive suspension of micro-organisms in the water column (resuspension model), and the second one also at high tide, where the physical forcing was not sufficient to induce resuspension (sedimentation model). As a consequence, an insignificant quantity of particles is suspended via biological factors as macrofauna bioturbation and it counterparts by a strong sedimentation of organic matter.

The inverse modelling can be divided into 3 steps: (i) determine the species that compose the food web, and all possible flows between them. Twenty-one compartments were listed (Table 1) linked by 115 or 118 flows for the models with and without resuspension, respectively. (ii) determine the mass balance of each compartment and constrains flow values by in situ measurements. (iii)limite possible values of flows by biological constraints.

\subsubsection{Considered compartments and flows}

\subsubsection{Resuspension and sedimentation}

A portable erodimeter (Guizien et al., 2012) was used to estimate the erosion shear stress of in situ cohesive sediments. An increased shear stress (by small steps, each timed to last about 10 minutes) was applied to the mud surface and the suspension of micro-organisms inhabiting in the sediment was monitored by changes in water column micro-organisms concentration. From these experiments, it was defined that resuspension of the microorganisms and diatoms took place when the shear bed velocity was higher or equal to $3 \mathrm{~cm} . \mathrm{s}^{-1}$. Sedimentation could not occur at higher current velocity.

Sedimentation was only considered in the model without resuspension, because the lower current velocity $\left(<3 \mathrm{~cm} \cdot \mathrm{s}^{-1}\right)$ allowed particles to settle down on the bottom during the slack water. The sedimentation rate was estimated from the formula $\mathrm{D}=\mathrm{Ws} * \mathrm{C}$ where $\mathrm{D}$ is expressed in $\mathrm{mgC} \cdot \mathrm{m}^{-2} \cdot \mathrm{h}^{-1}, \mathrm{C}$ is the concentration of particles in the water column $\left(\mathrm{mgC} \cdot \mathrm{m}^{-3}\right)$ and $\mathrm{Ws}$ the 
sinking velocity of particles $\left(\mathrm{m} \cdot \mathrm{h}^{-1}\right)($ Krone, 1962). Concentration of both pelagic bacteria and chlorophyll $a$ were measured in situ. The minimal limit for the concentration of the particulate carbon corresponded to the pelagic particulate carbon produced during high tide. For defining its maximal limit we considered that the import of carbon into the water column was equal to the amount of the benthic particulate carbon resuspended in the water column and not consumed. Consequently, it was assumed that the particulate carbon present in the water column at high tide, when resuspension occurred was likely to be found in a similar quantity at high tide $n+1$.

\subsubsection{The microphytobenthos}

Primary production of the microphytobenthos is linked to the biomass of diatoms present in the biofilm and to light conditions (Macintyre et al., 1996). During immersion, the turbidity of the overlying water, stopping the penetration of light (Alpine and Cloern, 1988) inhibits benthic primary production (Denis and Desreumaux, 2009; Migné et al., 2009). Moreover, just before the flood return, the diatoms move down into the sediment (Herlory et al., 2004; Round and Palmer, 1966). In our models, no microphytobenthic production was considered. The only input to the microphytobenthos compartment is thus an import of carbon which comes from the production of the previous diurnal low tide by the microphytobenthos, andwhich was not consumed during low tide. The import of carbon to the high tide corresponded to the export of carbon determined for microphytobenthos in a low tide model and was equal to $31.9 \mathrm{mgC} . \mathrm{m}^{-2}$ per high tide(Saint-Béat et al., 2013). Moreover the secretion of EPS, related to the activity of photosynthesis and migration (Underwood and Paterson, 2003), was supposed negligible at high tide (Hanlon et al., 2006). This was confirmed by a survey of EPS concentration in a tidal mesocosm during a tidal cycle showing a fall of EPS concentration in the biofilm during high tide (Agogué et al., present issue) 
9.7mgC of benthic diatoms were resuspended per high tide (Dupuy et al., present issue); they constitute a flow from the benthos to the pelagos that enhances the phytoplanktonic biomass after resuspension (Brito et al., 2012; Koh et al., 2006). In this way, the microphytobenthos constitutes a food resource for the secondary producers in pelagic and benthic ecosystems (Guarini et al., 1998; Riera and Richard, 1996; Yoshino et al., 2012).

\subsubsection{Benthic bacteria}

Biofilms (i.e an assemblage of benthic diatoms and bacteria) were reconstituted in a tidal mesocosm: the production and the biomass of the bacteria were measured during 5 days at low and high tides (Agogué et al., present issue). . The benthic bacterial production was estimated by tritiated thymidine incorporation (Garet and Moriarty, 1996), whichwas converted to numbers of cells using the ratio of $1.96 * 10^{17}$ cells per mol of thymidine determined for this study. A mean increase of $24.3 \%$ of the bacterial production in comparison to the bacterial production at low tide was observed in mesocosm experiments. The bacterial biomass was obtained from the mean cell volume calculated with Furhman's formula (1981) and converted in carbon units from the formula $133.754 * V^{0.438}\left(\mathrm{Vin} \mu \mathrm{m}^{3}\right)$ (Romanova and Sazhin, 2010). The carbon contain in a bacterium was thus estimated as equal to $79 \mathrm{fg} \mathrm{C}$. cell ${ }^{-1}$ for a mean biovolume of $0.28 \mu \mathrm{m}^{3}$ During erosion experiments at the threshold velocity considered in this study, $58.2 \mathrm{mgC}$ per high tide issued from the benthic bacteria were suspended (Dupuy et al., present issue). A part of the suspended bacteria were damaged or dead during the erosion process (40\%) (Mallet et al., present issue), and thus they integrated the pelagic particulate organic carbon compartment. On the contrary the remaining suspended benthic bacteria, still active, were considered to increase the pelagic bacteria biomass (Mallet et al., present issue). 
239 The microphytobenthos is the preferential resource of the benthic fauna but in case of unavailability of microphytobenthos, bacterivory becomes significant (Pascal et al., 2009). At high tide, bacterivory was supposed to be higher than the low tide values: the values of low tide used in the previous model (Saint-Béat et al., 2013) were thus integrated to high tide models as minimal values. The obligate as well as facultative suspension feeders were assumed to feed on particles from bacteria to mesozooplankton (Self and Jumars, 1988; Taghon, 1982).

\subsubsection{Phytoplankton}

The primary production of the phytoplankton was estimated for six other sites in MarennesOléron Bay based on in situ measurement of chlorophyll $a$ water concentration, salinity, temperature and depth profiles of light attenuation (Struski and Bacher, 2006). The phytoplanktonic primary production is influenced by the erosion of sediment, limited light penetration and by the resuspension of benthic diatoms which likely participate to the phytoplanktonic production (Macintyre et al., 1996). In order to prevent any bias in the estimation of the planktonic primary production, we constrained it by minimal and maximal primary production values measured in summer for the different stations of the bay. These stations are characterized by different hydrological conditions and are thus characterized by different resuspension and turbidity, and consequently by a different light penetration. Constraining the phytoplanktonic production by a range of possible values allowed to adjust the probability density function for gross primary production according to the needs of the food web based on the situation considered (i.e. with or without resuspension).

\subsubsection{Pelagic bacteria}


The summer abundance and the summer production of the pelagic bacteria were measured in situ (Ory et al., 2011). Bacteria were counted by epifluorescence microscopy after being fixed with $0.02 \mu \mathrm{m}$ filtered formaldehyde ( $2 \%$ final concentration) and staining for $30 \mathrm{~min}$ with Sybr Green I (for more details see Noble and Fuhrman, 1998; Ory et al., 2011). The measurement of AMPase $\left(\mathrm{V}_{\max }\right)$, which is considered as an indicator of the bacterial production, was used to estimate the bacterial production from the equation $\log \mathrm{BP}=$ $0.9271 * \log V \max +5.3641\left(\mathrm{r}^{2}=0.67, \mathrm{n}=10, \mathrm{p}=0.003\right)$. Pelagic bacteria being assumed to contain 16 fgC per cell (Labry et al., 2002), the bacterial production was thus expressed in carbon.

Experiments on viral lysis were conducted to test the interactions between bacteria, heterotrophic nanoflagellates (HNF) and viruses in the water column. In artificial incubations, they were re-combined to mimic the field assemblage with respect to the natural viral to bacterial ratio (VRB) and the bacteria to flagellates ratios. Fractionation allowed creating experimental recombined treatments and then differentiating between the direct and indirect interactions of the presence/absence of the virus and HNF. Through in vitro experiments, bacterial losses induced by viruses and flagellates were estimated by comparing the reduction of the bacteria cell production (MBP) between the different experimental assemblages.

\subsubsection{Benthic and pelagic viruses}

Viral lysis was estimated from viral production (i.e. net increase of viral abundance divided by the time of the experiment) within $2 \mathrm{~L}$ bottle incubations in the presence or absence of benthic particulates in order to determine the effect of the biofilm resuspension on the viral lysis. Bacterial mortality due to viral lysis was calculated from the viral production divided by the burst-size viruses (i.e. number of viruses produced by a bacterium at burst-time) which was estimated as 33 in this study (Montanié, pers. comm.). The quantity of viruses produced 
per time unit was converted into carbon considering that one virus contains $0.2 \mathrm{fgC}$ (Magagnini et al., 2007; Suttle, 2005).

The viral lysis of benthic bacteria at high tide was considered to be similar to the one at low tide, thus we considered that $40 \%$ of the bacterial production was lost by viral lysis (SaintBéat et al., 2013). At high tide, the benthic viruses were suspended and integrated into the pelagic virus compartment. $1.29 \mathrm{mgC}$ per high tide of virus per $\mathrm{m}^{2}$ were resuspended in the water column at the critical shear bed velocity of $3 \mathrm{~cm} \cdot \mathrm{s}^{-1}$ (Dupuy et al., present issue) determined by the erosion experiment (see above).

\subsubsection{Ciliates and heterotrophic Nanoflagellates}

The biomasses were expressed in carbon from a conversion factor of $19 \mu \mathrm{gC} . \mu \mathrm{m}^{3}{ }^{3}$ (Putt and Stoecker, 1989) by considering equivalent spherical diameter (ESD). The abundances and biomass of Ciliates (ESD $<50 \mu \mathrm{m})$ and heterotrophic nanoflagellates $(2 \mu \mathrm{m}<\mathrm{ESD}<10 \mu \mathrm{m})$ were estimated in situ. The seawater was filtered onto $0.8 \mu \mathrm{m}$ Nucleopore black filter. The ciliates and nanoflagellates were enumerated by epifluorescence microscopy. Cells were first fixed by the glutaraldehyde and the paraformaldehyde and stained with the lugol $1 \%$ and DAPI respectively.

In the models, phytoplankton and pelagic bacteria are prey of the compartments ciliates and nanoflagellates, which are themselves the preys of ciliates. The nanoflagellates also potentially graze the viruses (Bettarel et al., 2005; Manage et al., 2002).

\subsubsection{Mesozooplankton}

Mesozooplankton $(200 \mu \mathrm{m}<\mathrm{ESD}<400 \mu \mathrm{m})$ play a central role in the pelagic food web in the Marennes-Oléron Bay (Sautour and Castel, 1998) and show a variable diet (Vincent and Hartmann, 2001). The resources of mesozooplankton, as confirmed by bottle grazer 
experiments, in the area of Brouage mudflat are phytoplankton, either directly or indirectly via ciliates and the heterotrophic nanoflagellates (Azémar et al., 2007). This diet can be completed by the ingestion of detritic matter (David et al., 2006).

The abundance and the biomass of the mesozooplankton were estimated during study period.

The mesozooplankton was sampled using a $200 \mu \mathrm{m}$ mesh WP2 net, preserved in buffered formaldehyde with $\mathrm{Na}\left(\mathrm{Bo}_{3}\right)_{4}$ (final concentration 5\%) and counted under binocular microscope. The biomasses were expressed in carbon by multiplying the dry weight by 0.4 (Simard et al., 1985). These measurements were completed by bottle grazer experiments to test the effects of the biofilm suspension on the grazing of mesozooplankton. Water from the erodimeter (after erosion experiments) was mixed with filtered pelagic water $(200 \mu \mathrm{m}$, in order to exclude mesozooplankton) in different proportions $(20,40$ or $70 \%)$. This mix was transferred in $1.13 \mathrm{~L}$ Nalgene bottles and and incubated during 12 or $24 \mathrm{~h}$ in presence/absence (temoin) of mesozooplankton predators collected in situ. The resuspended biofilm in the water disturbs the trophic interactions of the mesozooplankton, especially through an inhibition of the grazing of phytoplankton and heterotrophic nanoflagellates by the mesozooplankton (Hartmann, pers. comm.). Thus in the model with the resuspension no flow between phytoplankton and nanoflagellates towards mesozooplankton was considered.

Main species able to graze on mudflat at high tide are mullets (Liza ramada and Liza aurata).

\subsubsection{Grazing Fishes}

Observed individuals arrive on the mudflat with an empty stomach, while they leave it with a full stomach (Carpentier et al., present issue). Thus the mullets were considered as a vector of carbon export. Since, the abundance of individuals going about the Brouage mudflat at high tide could not be measured in situ, grazing traces left by mullets on mudflat were considered as a proxy of their grazing pressure. Presence of traces was estimated from pictures of one 
square meter quadrats (expressed by surface of sediment removed by mullets by square meter). In addition, experiments on the feeding behavior of mullets were conducted in mesocoms to assess the volume of sediment ingested per individual at each tide (Como et al., present issue)). The coupling with field pictures finally allowed estimating the density of fishes per square meter.

\subsubsection{Imports and exports}

For all benthic compartments, we considered that the production during the previous low tide was not totally consumed, thus imports of carbon from the diurnal low tide were taken into account. These import values corresponded to the mean export values of the low tide model (Saint-Béat et al., 2013). Export was considered for both models regarding the microphytobenthos and the macrofauna, while export was considered only in the model without resuspension regarding the benthic particulate carbon and the dissolved particulate carbon. For the pelagic compartment, no import from the open sea was considered in the model with resuspension and an import from the open sea of pelagic particulate carbon was considered in the model without resuspension. We supposed that the production of the pelagos was totally consumed during the high tide, thus no export from the bay to the open sea of carbon was considered except for the pelagic particulate carbon, when the suspension occurred.

\subsubsection{Equations}

The second step characterizes the mass balances of each compartment (listed in Table S1) and flows measured in the field. These two elements (i.e. mass balance and equations) were written within an equation: $A * x=b$ where $x$ was vector that contained possible flows, the matrix $A$ expressed the mass balance and the field observation as a combination of 
coefficients of the carbon flows and the vector $b$ contained value of mass balances and values of known flows (Vézina, 1989). The mass balances correspond to the report of inputs and outputs for each compartment of the food web. By default, a compartment is considered to be at the equilibrium (i.e. a constant biomass). Concerning the model with suspension we needed to consider standing stock of the benthic particulate carbon and the benthic dissolved carbon in deficit. Indeed, for these two compartments, there was a net change in mass equal to resuspension term for particulate carbon and equal to the minimal value necessary to the running of model for the dissolved organic carbon. In the case without resuspension, we considered that the biomass loss of pelagic bacteria was equal to the value of the sedimentation. The other sets of equations corresponded to the values of flows, which were measured in situ.

\subsubsection{Inequalities}

At the last step, some biological constraints were added to the mass balances and flow values. These constraints were obtained from the literature and limit the possible solutions of flows to realistic values. The information was added to the model with the inequality: $G * x \leq h$, where $x$ remains the vector containing flows, $G$ is a matrix that contains the coefficients of the biological constraints and the vector $h$ is composed of values of biological constraints (Vézina, 1989). For the benthic compartments the set of inequalities of the low tide model (Saint-Béat et al., 2013) was used. When the constraints corresponded to a value of flows, the value of this constraint was updated according to the time of high tide (8h). The inequalities for the pelagic compartments were grouped in the Table 2.

The sedimentation flows values were limited, considering two different sinking velocities, which is different according to the particle size (De La Rocha and Passow, 2007). The minimal sinking velocity corresponded to the sinking velocity of a single isolated particle. We 
considered a minimal sinking velocity of $0.05 \mathrm{~m} . \mathrm{d}^{-1}$ for free bacteria (Lapoussière et al., 2011), $0.25 \mathrm{~m} . \mathrm{d}^{-1}$ for chlorophyll $a$ (Lapoussière et al., 2011) and $2.32 \mathrm{~m} . \mathrm{d}^{-1}$ for particulate carbon (Burns and Rosa, 1980). The maximal sinking velocity referred to the sinking velocity of 'marine snow', that are defined as organic aggregates with a diameter $>0.5 \mathrm{~mm}$ (Alldredge and Silver, 1988). The maximum sinking velocity chosen for this study was $16 \mathrm{~m} \cdot \mathrm{d}^{-1}$ (Turner, 2002). We considered that pelagic dissolved carbon can fall with the aggregates formed by 'marine snow' and represents one third of the total carbon in aggregates (Alldredge, 2000).

\subsubsection{Calculation of solutions}

The generated matrices ( $\mathrm{A}, \mathrm{b}, \mathrm{G}$ and $\mathrm{h}$ ) define a multi-dimensional space delimiting possible solutions of the flows (x). The MCMC-LIM mirror (Van den Meersche et al., 2009) was used to sample through that solution space in an attempt to map it completely._The MCMC-LIM, based on the mirror technique defined by Van Den Meersche et al.(2009) and updated for LIM use by van Oevelen et al. (2010), calculates several solutions and allows a direct characterization of the uncertainty. This modelling technique brings the advantage of calculating a range of possible values for each flow (i.e. a probability density function). For each model (with resuspension and without resuspension), 500, 000 iterations with a jump of 0.5 were calculated. The length of jump and the number of iterations were determined to cover the solution space as completely as possible. In this study the simulations were realized with a MATLAB ${ }^{\odot}$ translation conceived by Alain Vézina and Lauriane Campo of the RCRAN project package LIM-Solve created by Van den Meersche et al. (2009).

\subsubsection{Network analysis}

From the 500,000 solutions estimated by MCMC-LIM, seven ecological network analysis (ENA) indices were calculated. These indices allow assessing the structure and the 
functioning of the two food webs. The magnitude of cycling within the system was described by the Finn cycling Index (i.e. FCI). This index represents the fraction of flows involved in the cycling (Finn, 1976). A cycle represents a series of transfers between components in an ecosystem beginning and ending in the same compartment without going through the same compartment twice. The FCI is estimated by the ratio Tc/TST, where TST is the total system throughput (i.e. sum of all flows) and Tc the amount devoted to cycling. Various global indices describe the developmental and organizational state of the ecosystem (Ulanowicz, 1986). The TST measures the activity of the whole ecosystem. The TST can be considered as the total power generated within the system (Baird et al., 1998). The AMI value is indicative of the specialization of flows in the network (Ulanowicz, 2004). The probability of flows between two compartments increases with the AMI value, and thus with the specialization of flows. The Ascendency (A) which represents the state of organization within the ecosystem (Ulanowicz, 1986), is described as the product of the TST and the average mutual information (i.e. AMI). The development capacity (DC) is defined as the upper limit of Ascendency. The relative Ascendency is the ratio $\mathrm{A} / \mathrm{DC}$ and estimates the proportion of the network that is organized and thus efficient. The $(\mathrm{DC}-\mathrm{A})$ difference estimates the inefficient part of the network, corresponding to the overheads (i.e. overheads on imports, exports and dissipation) and redundancy, that measures the uncertainty associated to the presence of multiple or parallel pathways among the compartments (Ulanowicz and Norden, 1990). The internal Ascendency $\left(\mathrm{A}_{\mathrm{i}}\right)$ and internal development capacity $\left(\mathrm{DC}_{\mathrm{i}}\right)$ refer to internal exchanges alone and exclude the exogenous flows.

These indices were estimated using MATLAB $^{\odot}$ routine written by Carole Lebreton and Markus Schartau (GKSS Research Centre, Geesthacht, Germany) to calculate the index value for every solution estimated by the LIM-MCMC. 
Since the distribution of the data did not follow a normal distribution a non-parametric test was used. The significance of the differences between the indices calculated for both networks with and without resuspension was controlled by the Wilcoxon test $(\alpha=0.01)$. The tested hypothesis was that the two data sets were issued from a continuous distribution with equal medians. Statistical tests is possible because using the LIM-MCMC technique on 500,000 solutions, 500,000 values of each ENA index were also calculated, as consequence we can use statistical tests which are not usually possible in such a context of food web modelling using static methods and at this level of functional diversity.

\section{Results}

\subsection{Flow values}

Some differences in flow values between the two conditions (i.e. with or without suspension)

451

452 were observed (Table S2). The pelagic primary production was higher with resuspension. On the whole, consumption rates remained the same irrespective of the condition, except for the bacterivory of heterotrophic nanoflagellates (doubled with resuspension), the bacterivory of nematodes (consumption without resuspension was 7 times higher than the value during resuspension), as well as herbivory of deposit-feeders (about twice higher without resuspension than with resuspension) and consumption on nematodes by grazing fishes that both doubled without suspension. The exudation of DOC by benthic bacteria increased without suspension contrary to the exudation of DOC by pelagic bacteria that was five times higher during resuspension. The mortality of phytoplankton (i.e. phyTOppc) was higher when resuspension occurred. The egestion of nematodes without suspension was twice the egestion during resuspension. The export of carbon from benthic compartment was higher without suspension. 


\subsection{Compartment activities}

465 Significant differences appeared according to the condition considered (Figure 2). The benthic

466

467 activity was stimulated by the sedimentation of micro-organisms of the water column. In contrast, the resuspension of micro-organisms inhabiting in the sediment stimulated the pelagic activity.

Several pelagic compartments were affected by the resuspension of micro-organisms. The phytoplankton (phy), the pelagic non-living compartments (i.e. particulate compartment (ppc) and dissolved organic carbon (pdc)) as well as the pelagic bacteria (bcp) had a higher activity in the case of resuspension. On the contrary the microphytobenthos, the benthic bacteria, the benthic non-living compartments were more active when sedimentation occurred.

\subsection{Diet and consumption}

Herbivory tended to represent a more important part in the pelagic system (Table 3). In contrast, bacterivory was higher in the benthic compartment. The resuspension of the microorganisms to the water column had an effect on bacterivory, herbivory and the ratio between them. In the pelagic part, the resuspension favored the bacterivory. On the contrary, the herbivory was favored in the case without resuspension. The herbivory and bacterivory in benthos were both higher without resuspension.

The ratios showed that the herbivory was dominant in the pelagos. Nevertheless, when resuspension occurred, the decline in the ratio (almost divided by 2) was due to a fall of herbivory as well as a rise in bacterivory. A fall in the ratio was observed regarding the benthos due to a decline in the bacterivory lower than in herbivory.

None of the compartment was affected by the resuspension (Figure 3). Conversely, the diet of nematodes was drastically altered during the resuspension phase (B). Whatever the 
resuspension occurred or not, the contribution of the microphytobenthos as a food item for nematodes did not change (about 15\%). On the contrary, benthic bacteria and detritus contributed to nematodes diet almost equally in the case without resuspension (40 and 30\%, respectively), while it mainly shifted to benthic particulate (about 80\%) in resuspension situation.

The detritus contributed only slightly to the diet of deposit feeders. This group fed mainly on microphytobenthos and benthic bacteria. The contribution of each of these two groups changed with the resuspension. While the consumption on the benthic bacteria remained the same between resuspension and sedimentation phases, it corresponded to a higher contribution to the deposit-feeder diet during resuspension.

The facultative suspension feeders fed on the planktonic and benthic species. The contribution of the phytoplankton to the diet of this group was higher when the resuspension occurred. Consequently, the microphytobenthos was merely consumed. In contrast, in the case without resuspension, the microphytobenthos contributed to $40 \%$ of the consumption and the phytoplankton for $20 \%$. The contribution of pelagic and particulate carbon tended to be lower with the resuspension.

The resuspension tended to have some consequences on the diet of the heterotrophic nanoflagellates and mesozooplankton (Figure 4). The diet of the heterotrophic nanoflagellates was more diversified during resuspension because of the contribution of virus (vrp). The contribution of pelagic bacteria (bcp) was three times higher in the case of resuspension. Consequently the contribution of the phytoplankton (phy) decreased. The most affected compartment was the mesozooplankton. Without resuspension the mesozooplankton fed equally on the phytoplankton, heterotrophic nanoflagellates, pelagic particulate carbon (ppc) and ciliates. During the resuspension, the consumption on both heterotrophic nanoflagellates and phytoplankton was inhibited. 
Significant differences between values of the indices of the two situations were observed AMI value) was observed. The higher relative Ascendency, coupled with a lower AMI value observed in the case of resuspension, suggested a lower diversity of flows. The overheads based on the imports, exports, respiration and redundancy of the system were lower during resuspension. The internal normalized Ascendency tended to be similar for the two situations. The proportion of flows involved in the cycling (i.e. FCI value) was lower during resuspension event.

\section{Discussion}

4.1. Activity of the benthic and the pelagic compartments

The benthos was more active than the pelagos regarding simulation without resuspension; in contrast the pelagic activity was higher during resuspension. This fact can be explained by a large import of particulate carbon to the pelagic particulate compartment. Without this import of pelagic carbon, the pelagic activity was equal to the benthic activity during resuspension. The higher benthic activity was previously shown in the model of the Brouage mudflat food web. In fact, the higher activity of the benthos was observed irrespective of the model considered in previous studies by regarding annual budget (Leguerrier et al., 2004) or by

534 deciphering seasonal budgets (Degré et al., 2006). However, in our model, the ranking of the compartments was modified. The main difference concerned the benthic bacteria and the microphytobenthos. The benthic bacteria dominated the ecosystem; they were followed by the benthic non-living detritus compartments. Surprisingly, the microphytobenthos was ranked 
only $8^{\text {th }}$. The difference with previous models is the time-scale considered: a mean year (Leguerrier et al., 2004) or a mean month (Degré et al., 2006) which is in dramatic contrast to the small scale mean immersion period integrated in our model. During immersion, because of darkness due to sediment burying, the microphytobenthos production was null (Blanchard, 2006). As a consequence, the carbon input to this compartment exclusively originated from the photosynthesis performed during the previous diurnal low tide, which might explain its $8^{\text {th }}$ rank in our model. The first pelagic compartments were ranked $4^{\text {th }}$ and $5^{\text {th }}$ and corresponded to the phytoplankton and the dissolved organic carbon, respectively.

The resuspension of the microbial biofilm stimulated the activity of the phytoplankton, the non-living compartments (detritus) and the pelagic bacteria. This stimulation was not only the consequence of the input of new matter in the water column. The phytoplankton showed a higher gross primary production when the resuspension of the microbial biofilm occurred. Pelagic primary production was not imposed to the model; it was only constrained by minimal and maximal values of pelagic production found for different hydrological conditions in Marennes-Oléron Bay. The higher production was somewhat surprising because the resuspension also generates a high turbidity and the reduction of the light penetration which dramatically reduces phytoplankton photosynthesis (Billerbeck et al., 2007; Porter et al., 2010). When buried in the sediments, the microphytobenthos can remove nutrients from the overlying water and the sediment pore water (Macintyre et al., 1996). Such activity tends to reduce the nutrient fluxes from the sediments to the water column which can limit the phytoplankton production (Sarker et al., 2009; Sloth et al., 1996). When the microphytobenthos resuspension occurs, the nutrient fluxes to the water column increase which has a positive effect on the phytoplankton production even if light is limiting (Porter et al., 2010). Paradoxically, the import of microphytobenthic diatoms to the water column contributes itself positively to the production of the phytoplankton (Macintyre et al., 1996). 
By enriching water in particulate and dissolved carbon, which sustained a higher bacterial activity as previously reported (Cotner et al., 2000; Poremba et al., 1999; Sloth et al., 1996), the resuspension also stimulated heterotrophic production.

On the contrary, the settling of pelagic micro-organisms to the bottom of the water column had smaller but significant consequences on the benthic compartments. In our model, the input of pelagic fresh matter to the benthos increased the stock of available carbon for higher trophic levels but it did not affect the production of the different compartments. The higher activity observed for the benthic compartments (mpb, bdc, bcb, bpc) (Figure 2) was linked to the deposit of pelagic diatoms, dissolved carbon, pelagic bacteria and particulate carbon respectively at the surface of the sediments. The photosynthetic production of the pelagic diatoms settled at the bottom of the water column during immersion is more probably limited by the penetration of light than by the nutrient availability. It is supposed that, in contrast to the light reaching the surface of the sediments (Billerbeck et al., 2007; Macintyre et al., 1996), nutrients are often not a limiting factor for the photosynthesis in the intertidal sediments (Migné et al., 2004; Serôdio and Catarino, 2000). The high turbidity reported in the bay of Marennes-Oléron (Raillard and Mesenguen, 1994) likely stops the light penetration to the sediment surface and strongly impairs the photosynthesis of pelagic diatoms. The effect of the settling on the benthic bacterial production is more obvious. The bacterial production depends on the substrate supply including organic carbon (Sander and Kalff, 1993). For instance in Kiel Bight, the settling of detritus stimulates the benthic bacterial production (Meyer-Reil, 1983). Consequently, it is very likely that the benthic bacterial production is stimulated in the Brouage mudflat during sedimentation. 
The massive resuspension event impacted the pelagic microbial food web. It stimulated the bacterivory of the pelagos as reported before for heterotrophic nanoflagellates (Garstecki et al., 2002). A higher quantity of carbon flowed through the virus (viral lysis was doubled) and consequently more virus were consumed by heterotrophic nanoflagellates. The increase of pelagic bacterial abundance and production doubled the bacterivory rate of heterotrophic nanoflagellates. In contrast, the resuspension tended to decrease the pelagic herbivory. In spite of a higher gross primary production and a direct input of benthic diatoms biomass to the water column, the phytoplankton was integrated to a lower proportion to the pelagic food web. Indeed, the grazing of phytoplankton by the mesozooplankton had been shown to be inhibited during catastrophic erosion event (Hartmann, pers.comm.). Consequently, our models showed that a lower part of the phytoplankton was consumed in the model with resuspension, inducing a greater mortality of this comportment. This result of the models (i.e. higher phyTOppc when resuspension occurs) is coherent with previous results of resuspension experiments (Porter et al., 2010). It thus appears that in conditions of resuspension, the phytoplankton indirectly participated to the enrichment of the water column in dissolved organic carbon and to the pelagic bacterial production.

The bacterivory dominated the benthic compartment during immersion irrespective of the resuspension. At high tide, benthic diatoms moves down the sediment and cannot perform photosynthesis because of the absence of light (Cartaxana et al., 2011). Hence, the benthic food web must be sustained by the input of carbon coming from the photosynthetic production of the previous emersion and by the bacterial production. In our model, we supposed that the meiofauna and the macrofauna showed a constant consumption along the day irrespective of immersion/emersion periods. This hypothesis was based on the assumption that the meiofauna and the deposit feeders had alternative resources since the microphytobenthos was not sufficient to sustain their respective metabolism. Detritus (van 
Oevelen et al., 2006) bacteria were possible alternative resource for benthic fauna (Pascal et

613 al., 2009; van Oevelen et al., 2006). Some isotopic analyses at the Brouage mudflat showed that the benthic detritus contributes to $11 \%$ in maximum to the deposit-feeders consumption (Richard, comm. pers.). We supposed that the alternative feeding resource was the benthic bacteria (see result section .

Previous studies on the bacterivory rates of the nematodes, the foraminifera and Peringia ulvae in the Brouage mudflat indeed showed that bacteria can constitute a significant alternative resource to the microphytobenthos under some conditions (Pascal et al., 2008a; Pascal et al., 2008b; Pascal et al., 2008c). When there was no resuspension, the herbivory and the bacterivory were both stimulated, although the bacterivory was stimulated in a larger proportion due to the higher activity of the nematodes. The bacterivory thus remained dominant in the benthic compartment irrespective of the physical forcing. The Sylt- Rømø Bight in the North of Germany is composed of a mosaic of habitats including a mudflat. Its benthic food web is based on microphytobenthos and macrophytes. In this benthic ecosystem, the herbivory dominates the bacterivory (Baird et al., 2004). Indeed, herbivory is more than two times higher than bacterivory. Thus the ratio herbivory/bacterivory of the Sylt-Røm $\varnothing$ Bight displays an opposite tendency than the ratio estimated for the Brouage mudflat. This opposite tendency may be linked to the fact that this ratio was obtained from the food web for the whole bay on a long term. As a consequence, habitats with high and low primary production were associated, thus the available carbon issued from the primary production was more important. Moreover, the food web considered in Baird et al. (2004) represents a mean day as a consequence the difference between low tide and high tide was not visible and the effect of the season was not considered contrary to present simulations, which focused on summer conditions and high tide only In this study, that considered the summer period, little carbon issued from the primary production at low tide was available. The consideration of the 
food web for the whole year at the Brouage mudflat should abate the seasonal difference and change the trend of herbivory/bacterivory ratio.

\subsection{Functioning of the Brouage food web}

For comparing the functional indices from our model to others, we took care of selecting ecosystem models that coupled the pelagic and benthic compartments. Moreover the nonliving compartments must be separated from bacteria, otherwise the ENA indices would be biased (Johnson et al., 2009). Values of relative Ascendency and internal relative Ascendency were in general higher to those previously reported. Relative Ascendency ranged from 33.4 (Monaco and Ulanowicz, 1997) to 49.5 for the Chesapeake Bay (Baird et al., 1991) and the internal Ascendency from 31.2 for the Delaware (Monaco and Ulanowicz, 1997) to 44.1 for the Sundays Bay (Scharler and Baird, 2005). The cycling estimated without resuspension was higher to the FCI (i.e. Finn Cycling Index) estimated in the Sylt- Rømø Bight $(=17.2 \%)$ and close to the value of Sundays Estuary (Scharler and Baird, 2005). The differences between our study and previous ones are most probably based on the shorter time scale in our models. In the aforementioned studies, the ecosystems considered are estuaries which are subjected to the tidal rhythm and thus which are controlled by strong temporal/physical forcing. It was demonstrated how physical parameters can influence the ecological properties described by the ENA indices (Niquil et al., 2012). The consequences of physical forcing like the resuspension are smoothed when the considered networks use flows averaged over a mean day, more representative of normal conditions without waves. Additionally, the biological processes change according to the immersion and the emersion periods which impacts the carbon budget (Migné et al., 2009). Consequently, when emersion and immersion are considered separately (i.e. short time scale), it allows more precisely deciphering the biological and physical processes that control the functioning of the food web. 
When the massive resuspension of the microbial biofilm occurred, the enrichment of the water column by the benthic particulate carbon (i.e. $3.584 \mathrm{gC} \cdot \mathrm{m}^{-2}$.per high tide) mainly supported the increased activity of the whole system and the decreased organization of the network decreased. The higher value of Ascendency $\left(2 * 10^{4} \mathrm{mgC} \cdot \mathrm{m}^{-2}\right.$.per high tide against $0.6^{*} 10^{4} \mathrm{mgC} . \mathrm{m}^{-2}$.per high tide during sedimentation) was the consequence of a higher TST (10000 mgC.m $\mathrm{m}^{-2}$.per high tide during resuspension and $3500 \mathrm{mgC} \cdot \mathrm{m}^{-2}$.per high tide during sedimentation), in spite of a drop down in the specialization of the trophic way (measured by AMI)This is a characteristic observation for a so-called "pulse eutrophication", an intermittent increase of organic matter supply combined with physical factors (Patrício et al ., 2004). Moreover a high value of Ascendency derived from a very high TST, could disturb the internal stability of the system (Ulanowicz, 2003). The lower overheads suggest a lower resistance to the perturbation as proposed by Ulanowicz (2003). Thus the resuspension decreased the resistance of the system to a perturbation. We propose that the massive resuspension event in the Brouage mudflat could be defined as a "pulse eutrophication" event that regularly disturbs the meta-ecosystem. On the contrary the biological erosion coupled with a high sedimentation tended to reduce the perturbation in the meta-system.

During the massive resuspension, the lower proportion of cycling (i.e. lower value of FCI) coupled with a high internal relative Ascendency (close to 50\%) can be explained by the limited integration to the planktonic food web of the non-living carbon suspended in the water column. Indeed, in spite of a higher pelagic bacterial production and a higher detritivory, a low quantity of carbon was recycled. As a consequence, almost all the carbon suspended in the water column (i.e. 3.534 gC.m ${ }^{-2}$.per high tide) was exported. Note that the export value was not constrained in the model, thus this value reflected a real property of the network. The larger the difference between the cycling and the internal relative Ascendency, the less organized and more under pressure a system would be (Baird et al., 2007; Baird et al., 1991). 
Thus the Brouage mudflat was less organized (confirmed by lower value of AMI) and submitted to a higher stress during the resuspension. A similar relation (i.e. great difference) between FCI and internal relative Ascendency was found for the mussel-bed in the Rømø-Sylt Bight (Baird et al., 2007) and in an upwelling area (Baird et al., 1991). Baird et al (1991) brought a significant nuance to the stress sense, by the distinction between ecosystems which are under physically or chemically pressure. Indeed, the two constraints do not refer to the same time scale. A chemical stress is in general recent and it has an exogenous origin to the considered ecosystem. In contrast, physical perturbations are older and the ecosystem can have adapted to it. These differences explain how a low cycling value can be coupled with a high internal relative Ascendency (Baird et al., 1991). During the massive resuspension phase, and as expected, the Brouage mudflat obviously showed the characteristics of a system that is physically perturbed.

When massive resuspension did not occur, the Brouage mudflat was characterized by a high specialization (i.e. high AMI) and by a relative Ascendency close to $60 \%$. Such value illustrates a state closed to the equilibrium between the efficient and the fraction of the network that has not yet been organized (Bodini and Bondavalli, 2002); it is based on redundancy in the imports, the exports, the dissipation and on internal redundancy (Baird et al., 2004). The equilibrium between both parts (relative Ascendency and overheads) is supposed to bring sustainability to the ecosystem (Ulanowicz et al., 2009); the inefficient part being used as a reserve that brings the necessary flexibility for the ecosystem sustainability. Moreover the high internal relative Ascendency is a strong sign that the system is relatively mature (Baird et al., 1991). The lower difference between internal relative Ascendency and FCI supposed a higher organization and a less disturbed system (Baird et al., 2007). Hence, without massive resuspension of the microbial biofilm, the Brouage system seems to be relatively mature and stable. 
As defined by Loreau (2003), a meta-ecosystem corresponds to the different ecosystems

715

which are linked together by spatial flows of energy and matter. The rise of the tide and the chemical/physical/biological processes, which are associated with the increase of the water level on the mudflat can be considered as spatial flows. Here, we considered two different events according to the hydrodynamical conditions: 1) the massive resuspension of benthic matter in the water column 2) the sedimentation of pelagic matter on the mudflat sediments associated to a biological resuspension induced by macrofauna activities. As described above, their respective impact on the functioning of the benthic and the pelagic food webs strongly differs. The massive resuspension tends to disturb the Brouage meta-system while the sedimentation stabilizes it. These opposite consequences can be explained by the difference in the intensity of the flows. When the massive resuspension occurs, the sum of flows from the sediments to the water column was strong (about $3654 \mathrm{mgC} . \mathrm{m}^{-2}$ per immersion) while during the sedimentation, it was only $10 \%$ of the flow during resuspension. The interaction between the benthic and the pelagic compartments also appeared weaker during sedimentation than during massive resuspension. As suggested by Levin (1999), a highly modular system (composed of strongly connected sub-systems which are connected by weak links) is a stable system. This concept could be transposed to the meta-ecosystem. We observed that the sedimentation constitutes a weak link between the two subsystems benthos and pelagos. In contrast the massive resuspension constitutes a strong link between benthos and pelagos. To conclude the stabilizing pattern of Levin is observed when sedimentation occurs and not during massive resuspension event. This conceptual step appears essential for the better understanding of (meta-)ecosystem structure and functioning in order to improve our prediction for their sustainability. 
737 Despite its visible destabilizing effect, the massive resuspension brought some benefits to the

738 Brouage meta-system. It stimulated the pelagic microbial food web by increasing both 739 phytoplanktonic and bacterial production, and by stimulating bacterivory. Because of the 740 coupling of beneficial and destabilizing effects, massive resuspension show features 741 characteristic of an intermediate disturbance (reviewed in Shea et al., 2004). An intermediate 742 disturbance can be defined as an event that alters the specific niche availability, for instance 743 by removing the biomass or changing the nutrient availability, while it maintains the general 744 biodiversity (Shea et al., 2004). A complementary and extensive study of the long term 745 massive resuspension frequency and its consequences on the Brouage meta-system would 746 allow to confirm the intermediate disturbance hypothesis.

\section{Acknowledgements}

749 This work was supported by the French ANR (National Research Agency) through the 750 VASIREMI Project "Trophic significance of microbial biofilms in tidal flats" (Contract ANR751 06-BLAN-0393-01). Blanche Saint-Béat's PhD work was financed by the CNRS and Région 752 Poitou-Charentes. 
Agogué, H., Mallet, C., De Crignis, M., Orvain, F., Mornet, F., Dupuy, C., present issue. Bacterial dynamics in a microphytobenthic biofilm: a tidal mesocosm approach. Journal of Sea Research.

Alldredge, A.L., 2000. Interstitial dissolved organic carbon (DOC) concentrations within sinking marine aggregates and their potential contribution to carbon flux. Limnology \& Oceanography 45, 12451253.

Alldredge, A.L., Silver, M.W., 1988. Characteristics, dynamics and significance of marine snow. Progress in Oceanography 20, 41-82.

Alpine, A.E., Cloern, J.E., 1988. Phytoplankton growth rates in a light-limited environment, San Francisco Bay Marine Ecology Progress Series 44, 167-173.

Azémar, F., Boulêtreau, S., Lionard, M., Muylaert, K., Vyverman, W., Meire, P., Tackx, M., 2007. Looking for general trends in trophic interactions among estuarine micro-and mesozooplankton. Journal of Plankton Research 29, i135-i147.

Baird, D., Asmus, H., Asmus, R., 2004. Energy flow of a boreal intertidal ecosystem, the Sylt-Rømø Bight. Marine Ecology Progress Series 279, 45-61.

Baird, D., Asmus, H., Asmus, R., 2007. Trophic dynamics of eight intertidal communities of the SyltRøm $\varnothing$ Bight ecosystem, northern Wadden Sea. Marine Ecology Progress Series 351, 25-41.

Baird, D., Luzckovich, J., Christian, R.R., 1998. Assessment of spatial and temporal variability in ecosystem properties of the St Marks National Wildlife Refuge, Apalachee Bay, Florida. Estuarine, Coastal and Shelf Science 47, 329-349.

Baird, D., McGlade, J.M., Ulanowicz, R.E., 1991. The Comparative Ecology of Six Marine Ecosystems. Philosophical Transactions of the Royal Society of London. Series B: Biological Sciences 333, 15-29.

Bassoullet, P., Le Hir, P., Gouleau, D., Robert, S., 2000. Sediment transport over an intertidal mudflat: Field investigations and estimation of fluxes within the 'Baie de Marennes-Oleron' (France). Continental Shelf Research 20, 1635-1653.

Bettarel, Y., Sime-Ngando, T., Bouvy, M., Arfi, R., Amblard, C., 2005. Low consumption of virus-sized particles by heterotrophic nanoflagellates in two lakes of the French Massif Central. Aquatic Microbial Ecology 39, 205-209.

Billerbeck, M., Røy, H., Bosselmann, K., Huettel, M., 2007. Benthic photosynthesis in submerged Wadden Sea intertidal flats. Estuarine, Coastal and Shelf Science 71, 704-716.

Blanchard, G., 2006. Analyse conceptuelle du système de production primaire microphytobenthique des vasières intertidales. Océanis 32, 215-235.

Blanchard, G.F., Guarini, J.M., Orvain, F., Sauriau, P.G., 2001. Dynamic behaviour of benthic microalgal biomass in intertidal mudflats. Journal of Experimental Marine Biology and Ecology 264, 85-100.

Blanchard, G.F., Simon-Bouhet, B., Guarini, J.M., 2002. Properties of the dynamics of intertidal microphytobenthic biomass. Journal of the Marine Biological Association of the United Kingdom 82, 1027-1028.

Bodini, A., Bondavalli, C., 2002. Towards a sustainable use of water resources: a whole-ecosystem approach using network analysis. International Journal of Environment and Pollution 18, 463 - 485 Breed, G.A., Jackson, G.A., Richardson, T.L., 2004. Sedimentation, carbon export and food web structure in the Mississippi River plume described by inverse analysis. Marine Ecology Progress Series 278, 35-51.

Brett, J.R., 1965. The Relation of Size to Rate of Oxygen Consumption and Sustained Swimming Speed of Sockeye Salmon (Oncorhynchus nerka). Journal of the Fisheries Research Board of Canada 22, 1491-1501.

Brito, A.C., Fernandes, T.F., Newton, A., Facca, C., Tett, P., 2012. Does microphytobenthos resuspension influence phytoplankton in shallow systems? A comparison through a Fourier series analysis. Estuarine, Coastal and Shelf Science 110, 77-84. 
Bruslé, J., 1981. Food and feeding in grey mullets, in: Oren, O.H. (Ed.), Aquaculture of grey mullets. Cambridge University Press, Cambridge, pp. 185-217.

Burns, N.M., Rosa, F., 1980. In situ measurement of the settling velocity of organic carbon particles and 10 species of phytoplankton. Limnology \& Oceanography 25, 855-864.

Cariou-Le Gall, V., Blanchard, G., 1995. Monthly HPLC measurements of pigment concentration from an intertidal muddy sediment of Marennes-Oléron Bay, France. Marine Ecology Progress Series 121, 171-179.

Carpentier, A., Como, S., Dupuy, C., Lefrançois, C., Feunteun, E., present issue. Foraging strategy of Liza spp. in an intertidal mudflat: evidence of the importance of the primary production (biofilm) for the species. Journal of Sea Research.

Cartaxana, P., Ruivo, M., Hubas, C., Davidson, I., Serôdio, J., Jesus, B., 2011. Physiological versus behavioral photoprotection in intertidal epipelic and epipsammic benthic diatom communities. Journal of Experimental Marine Biology and Ecology 405, 127-137.

Como, S., Lefrançois, C., Maggi, E., Antognarelli, F., Dupuy, C., present issue. Behavioral responses of juvenile Liza aurata to changes in coastal temperatures and consequences for benthic food resources. Journal of Sea Research.

Consalvey, M., Paterson, D.M., Underwood, G.J., 2004. The ups and downs of life in a benthic biofilm: migration of benthic diatoms. Diatom Research 19, 181-202.

Cotner, J.B., Johengen, T.H., Biddanda, B.A., 2000. Intense winter heterotrophic production stimulated by benthic resuspension. Limnology \& Oceanography 45, 1672-1676.

David, V., Sautour, B., Galois, R., Chardy, P., 2006. The paradox high zooplankton biomass-low vegetal particulate organic matter in high turbidity zones: What way for energy transfer? Journal of Experimental Marine Biology and Ecology 333, 202-218.

De Jonge, V.N., Van Beuselom, J.E.E., 1992. Contribution of resuspended microphytobenthos to total phytoplankton in the EMS estuary and its possible role for grazers. Netherlands Journal of Sea Research 30, 91-105.

De La Rocha, C.L., Passow, U., 2007. Factors influencing the sinking of POC and the efficiency of the biological carbon pump. Deep-Sea Research Part II: Topical Studies in Oceanography 54, 639-658.

Decho, A.W., 2000. Microbial biofilms in intertidal systems: an overview. Continental Shelf Research 20, 1257-1273.

Degré, D., Leguerrier, D., Armynot du Chatelet, E., Rzeznik, J., Auguet, J.C., Dupuy, C., Marquis, E., Fichet, D., Struski, C., Joyeux, E., Sauriau, P.G., Niquil, N., 2006. Comparative analysis of the food webs of two intertidal mudflats during two seasons using inverse modelling: Aiguillon Cove and Brouage Mudflat, France. Estuarine, Coastal and Shelf Science 69, 107-124.

delGiorgio, P.A., Cole, J.J., 1998. Bacterial Growth Efficiency in Natural Aquatic Systems. Annual Review of Ecology and Systematics 29, 503-541.

Denis, L., Desreumaux, P.E., 2009. Short-term variability of intertidal microphytobenthic production using an oxygen microprofiling system. Marine and Freshwater Research 60, 712-726.

Dupuy, C., Mallet, C., Guizien, K., Montanié, H., Bréret, M., Mornet, F., Fontaine, C., Nérot, C., Orvain, F., present issue. Sequential resuspension of components (virus, prokaryotes and protists) of biofilm by erodimetry experiments in the Brouage mudflat (French Atlantic coast): subsurface vertical distribution of microorganisms into the sediment. Journal of Sea Research.

Finn, J.T., 1976. Measures of ecosystem structure and function derived from analysis of flows. Journal of Theoretical Biology 56, 363-380.

Fuhrman, J.A., 1981. Influence of method on the apparent size distribution of bacterioplankton cells: Epifluorescence microscopy compared to scanning ellectron microscopy. Marine Ecology Progress Series 5.

Garet, M.J., Moriarty, D.J.W., 1996. Acid extraction of tritium label from bacterial DNA in clay sediment. Journal of Microbiological Methods 25, 1-4. 
Garstecki, T., Wickham, S.A., Arndt, H., 2002. Effects of Experimental Sediment Resuspension on a Coastal Planktonic Microbial Food Web. Estuarine, Coastal and Shelf Science 55, 751-762.

Gouleau, D., Jouanneau, J.M., Weber, O., Sauriau, P.G., 2000. Short-and long- term sedimentation on Montportail-Brouage mudflat, Marennes-Oléron Bay, France. Continental Shelf Research 20, 15131530.

Guarini, J.-M., Blanchard, G.F., Gros, P., Gouleau, D., Bacher, C., 2000. Dynamic model of the shortterm variability of microphytobenthic biomass on temperate intertidal mudflats. Marine Ecology Progress Series 195, 291-303.

Guarini, J.M., Blanchard, G.F., Bacher, C., Gros, P., Riera, P., Richard, P., Gouleau, D., Galois, R., Prou, geostatistical analysis of two comprehensive surveys in Marennes-Oleron Bay (France). Marine Ecology Progress Series 166, 131-141.

Guizien, K., Dupuy, C., Ory, P., Montanié, H., Hartmann, H., Chatelain, M., Karpytchev, M., 2013. Microorganism dynamics during a rising tide: Disentangling effects of resuspension and mixing with offshore waters above an intertidal mudflat. Journal of Marine Systems.

Guizien, K., Orvain, F., Duchêne, J.-C., Le Hir, P., 2012. Accounting for Rough Bed Friction Factors of Mud Beds as a Result of Biological Activity in Erosion Experiments. Journal of Hydraulic Engineering 138, 979-984.

Hanlon, A., Bellinger, B., Haynes, K., Xiao, G., Hofmann, T., Gretz, M., Ball, A.S., Osborn, A., Underwood, G., 2006. Dynamics of extracellular polymeric substance (EPS) production and loss in an estuarine, diatom-dominated, microalgal biofilm over a tidal emersion-immersion period. Limnology and oceanography 51, 79-93.

Haubois, A.G., Guarini, J.M., Richard, P., Fichet, D., Radenac, G., Blanchard, G.F., 2005. Ingestion rate of the deposit-feeder Hydrobia ulvae (Gastropoda) on epipelic diatoms: Effect of cell size and algal biomass. Journal of Experimental Marine Biology and Ecology 317, 1-12.

Hemmingsen, A.M., 1960. Energy metabolism as related to body size and respiratory surfaces, and its evolution. Reports of the Steno Memorial Hospital and Nordinsk Insulin Laboratorium 9, 6-110.

Herlory, O., Guarini, J.-M., Blanchard, G.F., 2004. Microstructure of microphytobenthic biofilm and its spatio-temporal dynamics in an intertidal mudflat (Aiguillon Bay, France). Marine Ecology Progress Series 282, 33-44.

Herman, P.M.J., Middelburg, J.J., Heip, C.H.R., 2001. Benthic community structure and sediment processes on an intertidal flat: results from the ECOFLAT project. Continental Shelf Research 21, 2055-2071.

Johnson, G.A., Niquil, N., Asmus, H., Bacher, C., Asmus, R., Baird, D., 2009. The effects of aggregation on the performance of the inverse method and indicators of network analysis. Ecological Modelling 220, 3448-3464.

Killen, S.S., Atkinson, D., Glazier, D.S., 2010. The intraspecific scaling of metabolic rate with body mass in fishes depends on lifestyle and temperature. Ecology Letters 13, 184-193.

Koh, C.H., Jong, S.K., Araki, H., Yamanishi, H., Mogi, H., Koga, K., 2006. Tidal resuspension of microphytobenthic chlorophyll a in a Nanaura mudflat, Saga, Ariake Sea, Japan: Flood-ebb and spring-neap variations. Marine Ecology Progress Series 312, 85-100.

Krone, R.B., 1962. Flume studies of the transport of sediment in estuarine shaoling processes., Hydraulic Engineering Laboratory and Sanitery Engineering Research Laboratory. University of California, Berkeley, CA.

Labry, C., Herbland, A., Delmas, D., 2002. The role of phosphorus on planktonic production of the Gironde plume waters in the Bay of Biscay. Journal of Plankton Research 24, 97-117.

Lapoussière, A., Michel, C., Starr, M., Gosselin, M., Poulin, M., 2011. Role of free-living and particleattached bacteria in the recycling and export of organic material in the Hudson bay system. Journal of Marine Systems 88, 434-445. 
Le Hir, P., Roberts, W., Cazaillet, O., Christie, M., Bassoullet, P., Bacher, C., 2000. Characterization of intertidal flat hydrodynamics. Continental Shelf Research 20, 1433-1459.

Leguerrier, D., Niquil, N., Petiau, A., Bodoy, A., 2004. Modeling the impact of oyster culture on a mudflat food web in Marennes-Oléron Bay (France). Marine Ecology Progress Series 273, 147-161. Levin, 1999. Fragile dominion: complexity and the commons. Reading, MA:Perseus Books.

Loreau, M., Mouquet, N., Holt, R.D., 2003. Meta-ecosystems: A theoretical framework for a spatial ecosystem ecology. Ecology Letters 6, 673-679.

Macintyre, H.L., Geider, R.J., Miller, D.C., 1996. Microphytobenthos: The ecological role of the 'secret garden' of unvegetated, shallow-water marine habitats. I. Distribution, abundance and primary production. Estuaries 19, 186-201.

Magagnini, M., Corinaldesi, C., Monticelli, L.S., De Domenico, E., Danovaro, R., 2007. Viral abundance and distribution in mesopelagic and bathypelagic waters of the Mediterranean Sea. Deep-Sea Research Part I: Oceanographic Research Papers 54, 1209-1220.

Mallet, C., Agogué, H., Bonnemoy, F., Guizien, K., Orvain, F., Dupuy, C., present issue. Resuspension of benthic prokaryotic communities during physical erosion process: an experimental approach. Journal of Sea Research.

Manage, P.M., Kawabata, Z., Nakano, S.I., Nishibe, Y., 2002. Effect of heterotrophic nanoflagellates on the loss of virus-like particles in pond water. Ecological Research 17, 473-479.

Mann, K.H., 1965. Energy Transformations by a Population of Fish in the River Thames. Journal of Animal Ecology 34, 253-275.

McCann, K., Hastings, A., Huxel, G.R., 1998. Weak trophic interactions and the balance of nature. Nature 395, 794-798.

Meyer-Reil, L.A., 1983. Benthic response to sedimentation events during autumn to spring at a shallow water station in the Western Kiel Bight. Marine Biology 77, 247-256.

Migné, A., Spilmont, N., Boucher, G., Denis, L., Hubas, C., Janquin, M.A., Rauch, M., Davoult, D., 2009. Annual budget of benthic production in Mont Saint-Michel Bay considering cloudiness, microphytobenthos migration, and variability of respiration rates with tidal conditions. Continental Shelf Research 29, 2280-2285.

Migné, A., Spilmont, N., Davoult, D., 2004. In situ measurements of benthic primary production during emersion: seasonal variations and annual production in the Bay of Somme (eastern English Channel, France). Continental Shelf Research 24, 1437-1449.

Moloney, C.L., Field, J.G., 1989. General allometric equations for rates of nutrient uptake, ingestion, and respiration in plankton organisms. Limnology \& Oceanography 34, 1290-1299.

Monaco, M.E., Ulanowicz, R.E., 1997. Comparative ecosystem trophic structure of three U.S. midAtlantic estuaries. Marine Ecology Progress Series 161, 239-254.

Montanié, H., Ory, P., Orvain, F., Delmas, D., Dupuy, C., Hartmann, H.J., present issue. Microbial interactions in marine water amended by eroded benthic biofilm: A case study from an intertidal mudflat Original Research Article. Journal of Sea Research.

Ni Longphuirt, S., Lim, J.H., Leynaert, A., Claquin, P., Choy, E.J., Kang, C.K., An, S., 2009. Dissolved inorganic nitrogen uptake by intertidal microphytobenthos: nutrient concentrations, light availability and migration. Marine Ecology Progress Series 379, 33-44.

Niquil, N., Chaumillon, E., Johnson, G.A., Bertin, X., Grami, B., David, V., Bacher, C., Asmus, H., Baird, D., Asmus, R., 2012. The effect of physical drivers on ecosystem indices derived from ecological network analysis: Comparison across estuarine ecosystems. Estuarine, Coastal and Shelf Science 108, 132-143.

Noble, R.T., Fuhrman, J.A., 1998. Use of SYBR Green I for rapid epifluorescence counts of marine viruses and bacteria. Aquatic Microbial Ecology 14, 113-118.

Orvain, F., Guizien, K., Lefebvre, S., Bréret, M., Dupuy, C., present issue. Relevance of biofilm features to understand the dynamic behavior of sediment erodability and microphytobenthos resuspension. Journal of Sea Research. 
Orvain, F., Sauriau, P.-G., Sygut, A., Joassard, L., Hir, P.L., 2004. Interacting effects of Hydrobia ulvae bioturbation and microphytobenthos on the erodibility of mudflat sediments. Marine Ecology Progress Series 278, 205-223.

Ory, P., Palesse, S., Delmas, D., Montanié, H., 2011. In situ structuring of virioplankton through bacterial exoenzymatic activity: Interaction with phytoplankton. Aquatic Microbial Ecology 64, 233252.

Pascal, P.Y., Dupuy, C., Richard, P., Haubois, A.G., Niquil, N., 2008a. Influence of environment factors on bacterial ingestion rate of the deposit-feeder Hydrobia ulvae and comparison with meiofauna. Journal of Sea Research 60, 151-156.

Pascal, P.Y., Dupuy, C., Richard, P., Mallet, C., Châtelet, E.A.D., Niquil, N., 2009. Seasonal variation in consumption of benthic bacteria by meio- And macrofauna in an intertidal mudflat. Limnology and Oceanography 54, 1048-1059.

Pascal, P.Y., Dupuy, C., Richard, P., Niquil, N., 2008b. Bacterivory in the common foraminifer Ammonia tepida: Isotope tracer experiment and the controlling factors. Journal of Experimental Marine Biology and Ecology 359, 55-61.

Pascal, P.Y., Dupuy, C., Richard, P., Rzeznik-Orignac, J., Niquil, N., 2008c. Bacterivory of a mudflat nematode community under different environmental conditions. Marine Biology 154, 671-682.

Patrício, J., Ulanowicz, R., Pardal, M.A., Marques, J.C., 2004. Ascendency as an ecological indicator: A case study of estuarine pulse eutrophication. Estuarine, Coastal and Shelf Science 60, 23-35.

Poremba, K., Tillmann, U., Hesse, K.J., 1999. Tidal impact on planktonic primary and bacterial production in the German Wadden Sea. Helgoland Marine Research 53, 19-27.

Porter, E.T., Mason, R.P., Sanford, L.P., 2010. Effect of tidal resuspension on benthic-pelagic coupling in an experimental ecosystem study. Marine Ecology Progress Series 413, 33-53.

Putt, M., Stoecker, D.K., 1989. An experimentally determined carbon: volume ratio for marine "oligotrichous" ciliates from estuarine and coastal waters. Limnology \& Oceanography 34, 10971103.

Raillard, O., Mesenguen, A., 1994. An ecosystem box model for estimating the carrying capacity of a macrotidal shellfish system. Marine Ecology Progress Series 115, 117-130.

Riera, P., Richard, P., 1996. Isotopic determination of food sources of Crassostrea gigas along a trophic gradient in the estuarine bay of Marennes-Oleron. Estuarine, Coastal and Shelf Science 42, 347-360.

Romanova, N., Sazhin, A., 2010. Relationships between the cell volume and the carbon content of bacteria. Oceanology 50, 522-530.

Rooney, N., McCann, K., Gellner, G., Moore, J.C., 2006. Structural asymmetry and the stability of diverse food webs. Nature 442, 265-269.

Round, F., Palmer, J., 1966. Persistent, vertical-migration rhythms in benthic microflora. J Marine Biol Assoc UK 46, 191-214.

Saint-Béat, B., Dupuy, C., Bocher, P., Chalumeau, J., De Crignis, M., Fontaine, C., Guizien, K., Lavaud, J., Lefebvre, S., Montanié, H., Mouget, J.-L., Orvain, F., Pascal, P.-Y., Quaintenne, G., Radenac, G., Richard, P., Robin, F., Vézina, A.F., Niquil, N., 2013. Key Features of Intertidal Food Webs That Support Migratory Shorebirds. PLoS ONE 8, e76739.

Sander, B.C., Kalff, J., 1993. Factors controlling Bacterial Production in Marine and Freshwater Sediments. Microbial Ecology 26, 79-99.

Sarker, M., Yamamoto, T., Hashimoto, T., 2009. Contribution of benthic microalgae to the whole water algal biomass and primary production in Suo Nada, the Seto Inland Sea, Japan. Journal of Oceanography 65, 311-323.

Sauriau, P.-G., Kang, C.-K., 2000. Stable isotope evidence of benthic microalgae-based growth and secondary production in the suspension feeder Cerastoderma edule (Mollusca, Bivalvia) in the Marennes-Oléron Bay. Hydrobiologia 440, 317-329. 
Sautour, B., Castel, J., 1998. Importance of microzooplanktonic crustaceans in the coastal food chain: Bay of Marennes-Oleron, France. Oceanologica Acta 21, 105-112.

Scharler, U.M., Baird, D., 2005. A comparison of selected ecosystem attributes of three South African estuaries with different freshwater inflow regimes, using network analysis. Journal of Marine Systems 56, 283-308.

Self, R.F.L., Jumars, P.A., 1988. Cross-phyletic patterns of particle selection by deposit feeders. Journal of Marine Research 46, 119-143.

Serôdio, J., Catarino, F., 2000. Modelling the primary productivity of intertidal microphytobenthos: time scales of variability and effects of migratory rhythms. Marine Ecology Progress Series 192, 1330.

Shea, K., Roxburgh, S.H., Rauschert, E.S., 2004. Moving from pattern to process: coexistence mechanisms under intermediate disturbance regimes. Ecology Letters 7, 491-508.

Simard, Y., Lacroix, G., Legendre, L., 1985. In situ twilight grazing rhythm during diel vertical migrations of a scattering layer of Calanus finmarchicus. Limnology \& Oceanography 30, 598-606.

Sloth, N.P., Riemann, B., Nielsen, L.P., Blackburn, T., 1996. Resilience of Pelagic and Benthic Microbial Communities to Sediment Resuspension in a Coastal Ecosystem, Knebel Vig, Denmark. Estuarine, Coastal and Shelf Science 42, 405-415.

Straile, D., 1997. Gross Growth Efficiencies of Protozoan and Metazoan Zooplankton and Their Dependence on Food Concentration, Predator-Prey Weight Ratio, and Taxonomic Group. Limnology and oceanography 42, 1375-1385.

Struski, C., Bacher, C., 2006. Preliminary estimate of primary production by phytoplankton in Marennes-Oléron Bay, France. Estuarine, Coastal and Shelf Science 66, 323-334.

Suttle, C.A., 2005. Viruses in the sea. Nature 437, 356-361.

Taghon, G.L., 1982. Optimal foraging by deposit-feeding invertebrates: Roles of particle size and organic coating. Oecologia 52, 295-304.

Tolhurst, T., Defew, E., De Brouwer, J., Wolfstein, K., Stal, L., Paterson, D., 2006. Small-scale temporal and spatial variability in the erosion threshold and properties of cohesive intertidal sediments. Continental Shelf Research 26, 351-362.

Turner, J.T., 2002. Zooplankton fecal pellets, marine snow and sinking phytoplankton blooms. Aquatic Microbial Ecology 27, 57-102.

Ulanowicz, R.E., 1986. Growth and Development. Ecosystems Phenomenology. Excel Press.

Ulanowicz, R.E., 2003. Some steps toward a central theory of ecosystem dynamics. Computational Biology and Chemistry 27, 523-530.

Ulanowicz, R.E., 2004. Quantitative methods for ecological network analysis. Computational Biology and Chemistry 28, 321-339.

Ulanowicz, R.E., Goerner, S.J., Lietaer, B., Gomez, R., 2009. Quantifying sustainability: Resilience, efficiency and the return of information theory. Ecological Complexity 6, 27-36.

Ulanowicz, R.E., Norden, J.S., 1990. Symmetrical overhead in flow networks. International Journal of Systems Science 21, 429-437.

Underwood, G.J.C., Paterson, D.M., 2003. The importance of extracellular carbohydrate production by marine epipelic diatoms, pp. 183-240.

Van den Meersche, K., Soetaert, K., Van Oevelen, D., 2009. xsample(): An R Function for Sampling Linear Inverse Problems. Journal of Statistical Software 30, 1-15.

van Oevelen, D., Moodley, L., Soetaert, K., Middelburg, J.J., 2006. The trophic significance of bacterial carbon in a marine intertidal sediments: Results of an in situ stable isotope labeling study. Limnology \& Oceanography 51, 2349-2359.

van Oevelen, D., van den Meersche, K., Meysman, F.J.R., Soetaert, K., Middelburg, J.J., Vézina, A.F., 2010. Quantifying food web flows using linear inverse models. Ecosystems 13, 32-45.

Vézina, A.F., 1989. Construction of flow networks using inverse methods., in: Wulff, F., Field, J.G., Mann, K.H. (Eds.), Network Analysis in Marine Ecology. Springer, Berlin, pp. 62-81. 
1049 Vezina, A.F., Pace, M.L., 1994. An inverse model analysis of planktonic food webs in experimental 1050 lakes. Canadian Journal of Fisheries and Aquatic Sciences 51, 2034-2044.

1051 Vézina, A.F., Platt, T., 1988. Food web dynamics in the ocean. I. Best-estimates of flow networks using inverse methods. Marine Ecology Progress Series 42, 269-287. Vincent, D., Hartmann, H.J., 2001. Contribution of ciliated microprotozoans and dinoflagellates to the diet of three copepod species in the bay of Biscay. Hydrobiologia 443, 193-204. Yoshino, K., Tsugeki, N.K., Amano, Y., Hayami, Y., Hamaoka, H., Omori, K., 2012. Intertidal bare mudflats subsidize subtidal production through outwelling of benthic microalgae. Estuarine, Coastal and Shelf Science 109, 138-143. 
Abbreviations

\begin{tabular}{lc}
\hline Benthos & \\
\hline Microphytobenthos & $\mathrm{mpb}$ \\
Benthic bacteria & $\mathrm{bcb}$ \\
Meiofauna & $\mathrm{mfb}$ \\
Nematodes & $\mathrm{nem}$ \\
Deposit-feeders & $\mathrm{dep}$ \\
Suspension-feeders & $\mathrm{sus}$ \\
Facultative suspension-feeders & $\mathrm{suf}$ \\
Omnivorous species & $\mathrm{omn}$ \\
Carnivorous species & $\mathrm{car}$ \\
Benthic viruses & $\mathrm{vrb}$ \\
Benthic particulate carbon & $\mathrm{bpc}$ \\
Benthic dissolved carbon & $\mathrm{bdc}$ \\
\hline Pelagos & \\
\hline Phytoplankton & phy \\
pelagic bacteria & $\mathrm{bcp}$ \\
Heterotrophic nanoflagellates & $\mathrm{hnf}$ \\
Cilliates & $\mathrm{cil}$ \\
Mesozooplankton & $\mathrm{mes}$ \\
Grazing fishes & $\mathrm{gfi}$ \\
Pelagic viruses & $\mathrm{vrp}$ \\
Pelagic particulate carbon & $\mathrm{ppc}$ \\
Pelagic dissolved carbon & $\mathrm{pdc}$
\end{tabular}

Table 1: List of compartments and used abbreviations. 


\begin{tabular}{|c|c|c|c|c|}
\hline Processes & Compartments & Lower limit & Upper limit & References \\
\hline Gross Growth Efficiency & HNF, CIL, MES & $10 \%$ & $40 \%$ & Straile, 1997 \\
\hline \multirow[t]{4}{*}{ Net Growth Efficiency } & $\mathrm{BCB}, \mathrm{BCP}$ & $11 \%$ & $61 \%$ & DelGiorgio and Cole, 1998 \\
\hline & MFB & $30 \%$ & $50 \%$ & van Oevelen et al. 2006 \\
\hline & NEM & $60 \%$ & $90 \%$ & \\
\hline & MAC & $50 \%$ & $70 \%$ & \\
\hline \multirow{5}{*}{$\begin{array}{l}\text { Assimilation Efficiency } \\
\text { (loss to the det) }\end{array}$} & HNF,CIL,MES & $50 \%$ & $90 \%$ & Vézina and Platt, 1988 \\
\hline & MFB & $57 \%$ & $97 \%$ & van Oevelen et al. 2006 \\
\hline & NEM & $6 \%$ & $30 \%$ & \\
\hline & MAC & $40 \%$ & $75 \%$ & \\
\hline & GFI & $50 \%$ & $90 \%$ & Leguerrier et al., 2004 \\
\hline \multirow[t]{4}{*}{ Excretion (loss to doc) } & HNF,CIL,MES & $10 \%$ of ingestion & $100 \%$ of respiration & min: Vézina and Pace, 1994 \\
\hline & & & & max: Vézina and Platt, 1988 \\
\hline & PHY & $10 \% \mathrm{NPP}$ & $55 \% \mathrm{NPP}$ & Breed et al., 2004 \\
\hline & & $5 \%$ GPP & $50 \% \mathrm{GPP}$ & Vézina and Platt, 1988 \\
\hline \multirow[t]{4}{*}{ Respiration } & HNF,CIL,MES & $20 \%$ of ingestion & - & Breed et al., 2004 \\
\hline & PHY, MPB & $5 \%$ GPP & $30 \% \mathrm{GPP}$ & Vézina and Platt, 1988 \\
\hline & MES & biomass $* 4.8 * \mathrm{~W}^{-0.25}$ & biomass $* 14 * \mathrm{~W}^{-0.25}$ & min: Hemmingsen, 1960 \\
\hline & CIL, HNF & biomass $* 0.6 * \mathrm{~W}^{-0.25}$ & biomass $* 1.7 * \mathrm{~W}^{-025}$ & max: Moloney and Field, 1989 \\
\hline Consumption / Biomass & GFI & $3 \%$ & $8 \%$ & Bruslé, 1981 \\
\hline $\begin{array}{l}\text { Gross primary production } \\
\left(\mathrm{mgC} \cdot \mathrm{m}^{-2} \cdot \mathrm{h}^{-1}\right)\end{array}$ & PHY & 10 & 50 & Struski and Bacher, 2006 \\
\hline \multirow{2}{*}{$\begin{array}{l}\text { Loss of doc for pelagic } \\
\text { bacteria (mgC.m-2.h-1) }\end{array}$} & $\mathrm{BCP}$ & 0.012 & - & in this study(with suspension) \\
\hline & & 0.005 & - & \\
\hline \multirow[t]{2}{*}{ Bacterivory by HNF } & HNF & - & $\begin{array}{l}49 \% \text { of the bacterial } \\
\text { production }\end{array}$ & in this study (with suspension) \\
\hline & $\mathrm{HNF}$ & - & $\begin{array}{l}45 \% \text { of the bacterial } \\
\text { production }\end{array}$ & in this study (without suspension) \\
\hline \multirow[t]{2}{*}{ Respiration (mgC.m-2.h-1) } & GFI & 0.226 & 3.628 & min: derived from Killen et al., 2010 \\
\hline & & & & max: derived from Brett, 1965 \\
\hline
\end{tabular}

1067 Table 2: List of biologial constraints used for the food web model. NPP: Net Primary 1068 Production, GPP: Gross Primary Production. W: body mass in pgC. Net Growth Efficiency = 1069 (consumption-detritus production-respiration)/ (consumption-detritus production), Gross 1070 Growth Efficiency=(consumption-loss to det-loss to doc-respiration)/ (consumption-loss to 1071 det-loss to doc- production). 


\begin{tabular}{lcccc} 
& Benthic & \multicolumn{3}{c}{ Pelagic } \\
\cline { 2 - 5 } & $\begin{array}{c}\text { With } \\
\text { resuspension }\end{array}$ & $\begin{array}{c}\text { Without } \\
\text { resuspension }\end{array}$ & $\begin{array}{c}\text { With } \\
\text { resuspension }\end{array}$ & $\begin{array}{c}\text { Without } \\
\text { resuspension }\end{array}$ \\
Herbivory (mgC.m-2.HT-1) & $20.4 \pm 0.1$ & $39.7 \pm 7.3$ & $28.7 \pm 11.2$ & $33.8 \pm 9.8$ \\
Bacterivory (mgC.m-2.HT-1) & $85.9 \pm 5.8$ & $123.7 \pm 42.7$ & $14.3 \pm 5.8$ & $8.1 \pm 3.2$ \\
Ratio herbivory/bacterivory & $0.2 \pm 0.01$ & $0.35 \pm 0.1$ & $2.9 \pm 3.1$ & $5.6 \pm 4.9$
\end{tabular}

Table 3: Mean values of herbivory and bacterivory in the benthos and the pelagos according to the resuspension of the biofilm. $\mathrm{HT}^{-1}=$ per High Tide. These values correspond to the mean and the standard deviation calculated from the 500,000 iterations calculated by the inverse analyses. For each compartment (i.e. benthos and pelagos), values were significantly different with or without resuspension (Wilcoxon test, $\mathrm{p}<0.05$ ) according to the condition considered. 


\section{Figures captions}

1084 1085

1086

1087

1088

1089

1090

1091

1092

1093

1094

1095

1096

1097

1098

1099

1100

1101

1102

1103

1104

1105

1106

1107

1108

1109

1110

1111

1112

1113

1114

Figure 1: Map of the study site: the Brouage mudflat within the Marennes-Oléron Bay.

Figure 2: Histogram presenting the activity of the compartments composing the food web. The activity corresponds to the sum of inflows and is expressed in $\mathrm{mgC} . \mathrm{m}^{-2}$ per high tide. A) corresponds to the sum of the activity of all compartments for the benthos and the pelagos according to the 2 modeled situations. B) and C) refer to the activity of each compartment of the benthos and of the pelagos. Compartments are sorted by top down activity in order to determine which ones of the compartments have higher contribution to the activity of the whole ecosystem according to the situation considered (i.e. sedimentation or resuspension). See table 1 for the abbreviations of the compartments.

Figure 3: Diet of the meiofauna and macrofauna. A) Top diagrams refer to the case without resuspension and B) down diagrams refer to the case where the resuspension occurred. The contribution corresponds to the fraction that represents the consumption on a prey in comparison to the total consumption. The contribution of each species to the compartment consumption was estimated from the mean value of each flow.

Figure 4: Diet of heterotrophic nanoflagellates (hnf), ciliates (cil) and mesozooplankton (mes). A) top diagrams refer to the simulation without resuspension and B) down diagrams refer to the simulation with resuspension. The contribution corresponds to the fraction that represents the consumption on a specific compartment in comparison to the total diet. The contribution of each species to the compartment consumption was estimated from the mean value of each flow.

Figure 5: Boxplots displaying the values of different ENA indices: the total System Throughput (TST), the Ascendency, the overheads, the relative Ascendency (A/DC), the Average mutual Information (AMI), the internal relative Ascendency (Ai/DCi) and the Finn Cycling index (FCI). The indices were calculated from the 500,000 solutions coming from the MCMC-LIM method. Red crosses correspond to outliers. Medians of all these indices were significantly different for the two seasons (Wilcoxon test, $\mathrm{H}_{0}$ was rejected, $\mathrm{p}$-value $<0.01$ ). 
1115 Figure 1

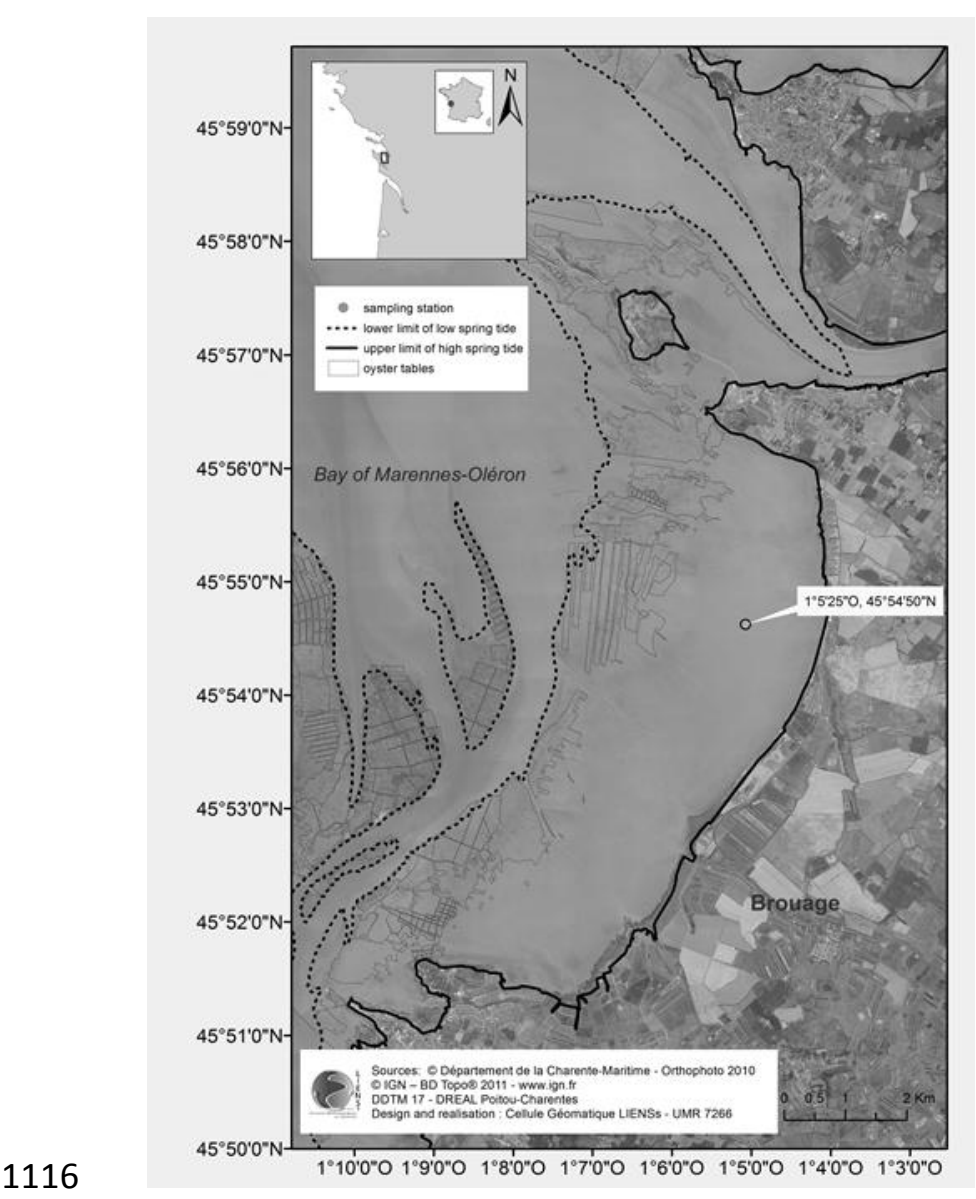

1117 
1118 Figure 2
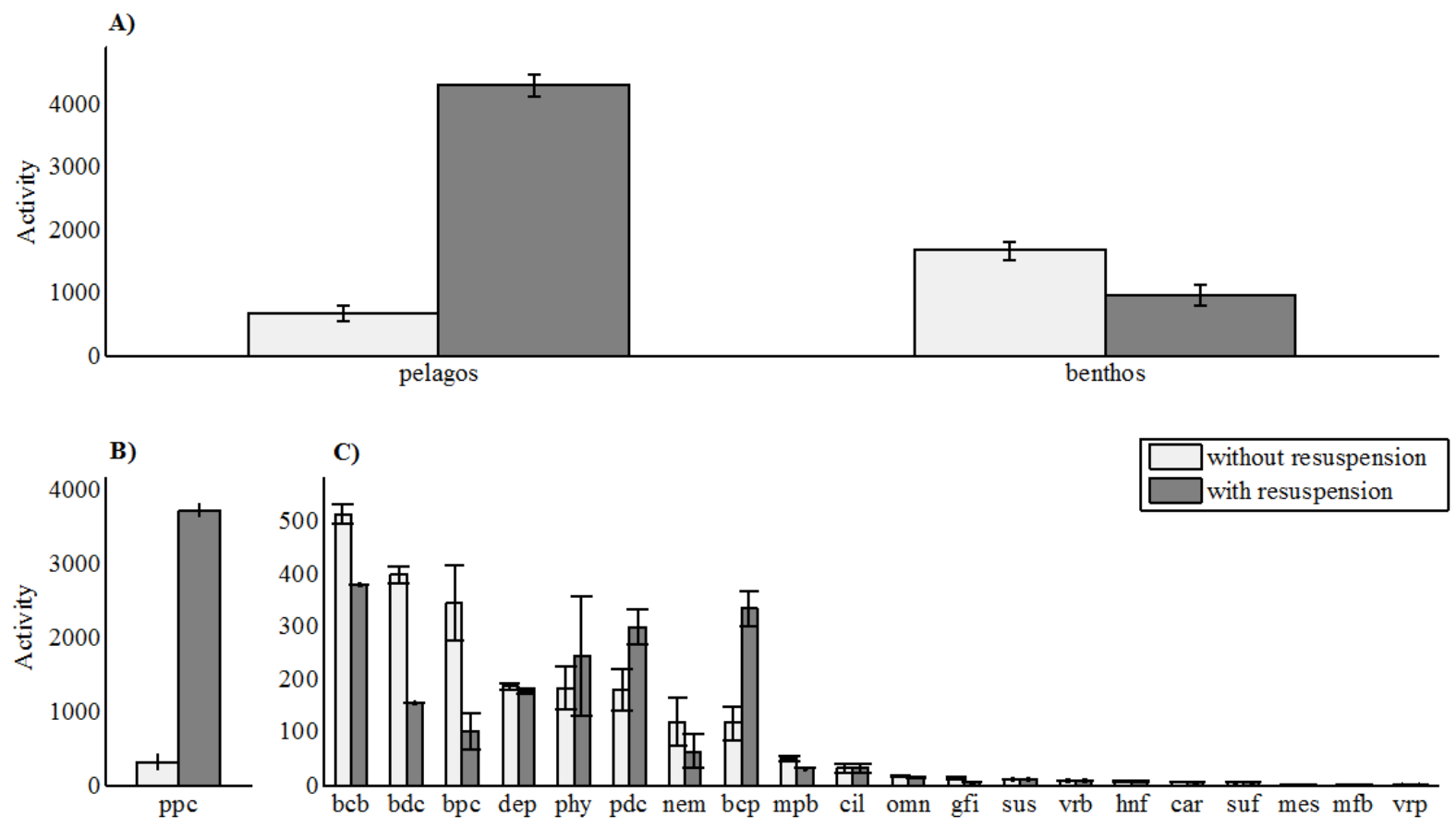
1121 Figure 3

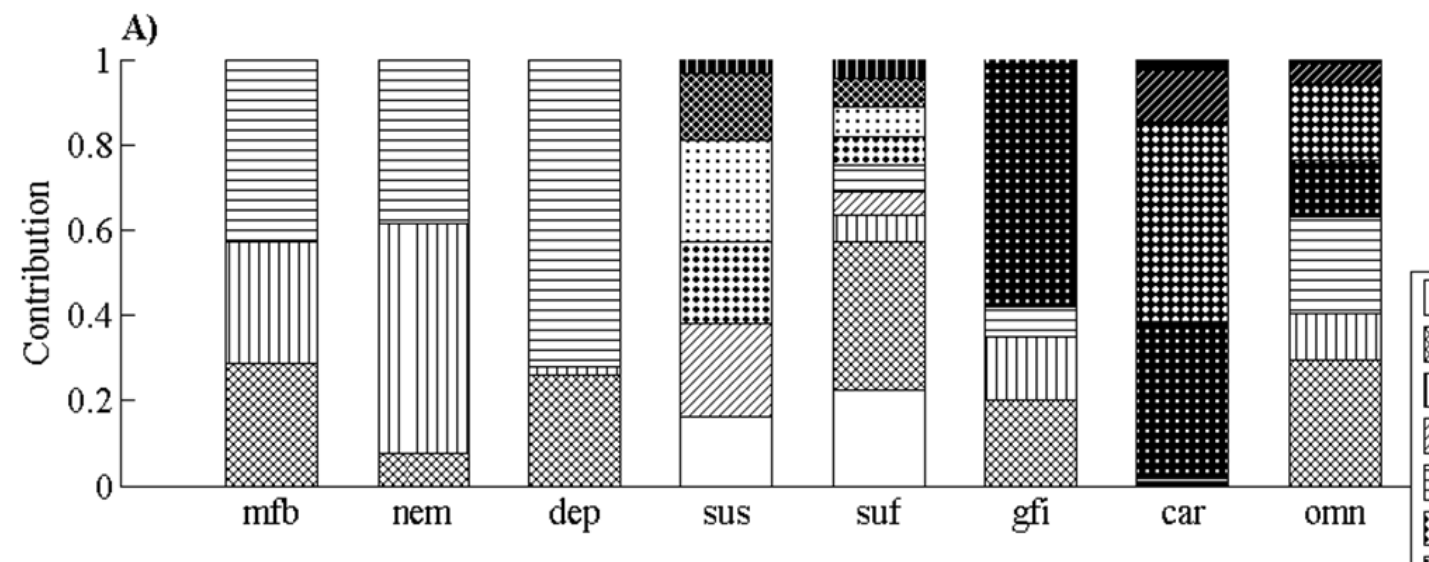

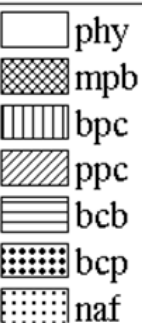

B)

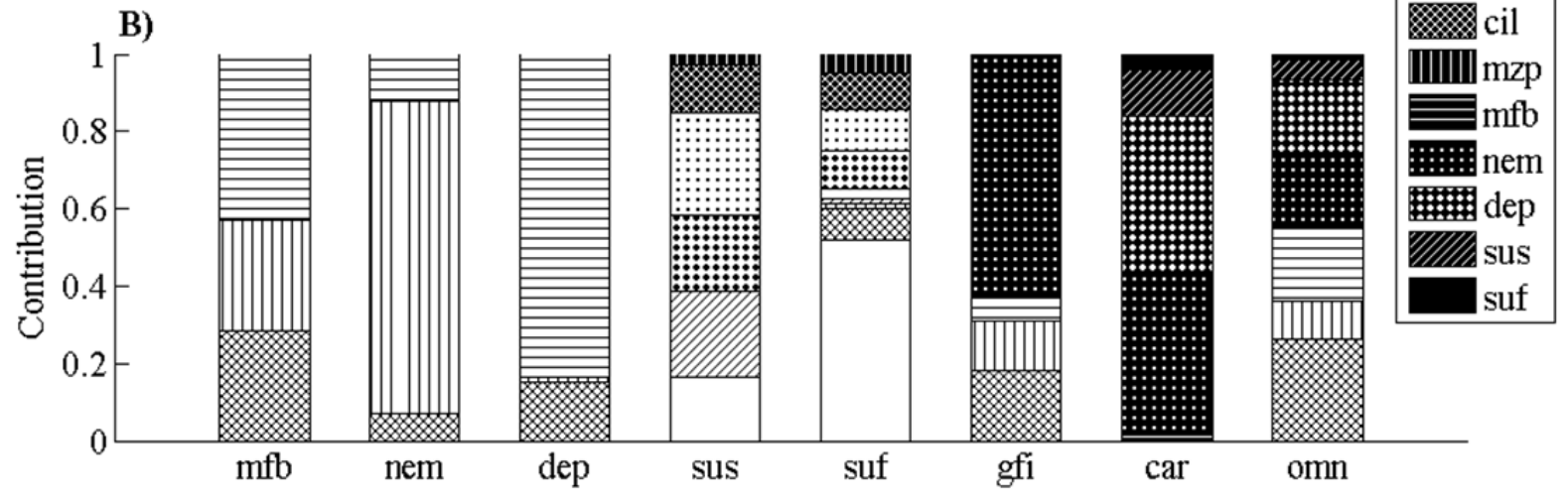

1123 
1124 Figure 4

1125

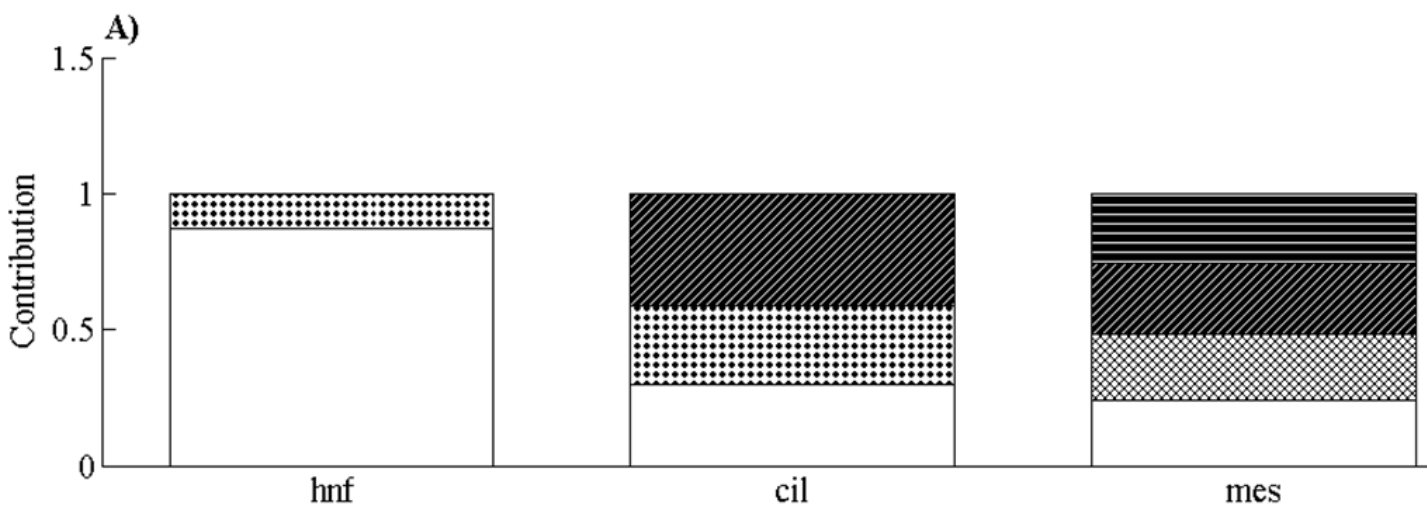

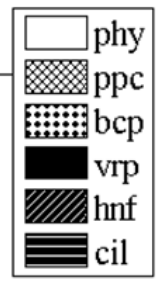

1126
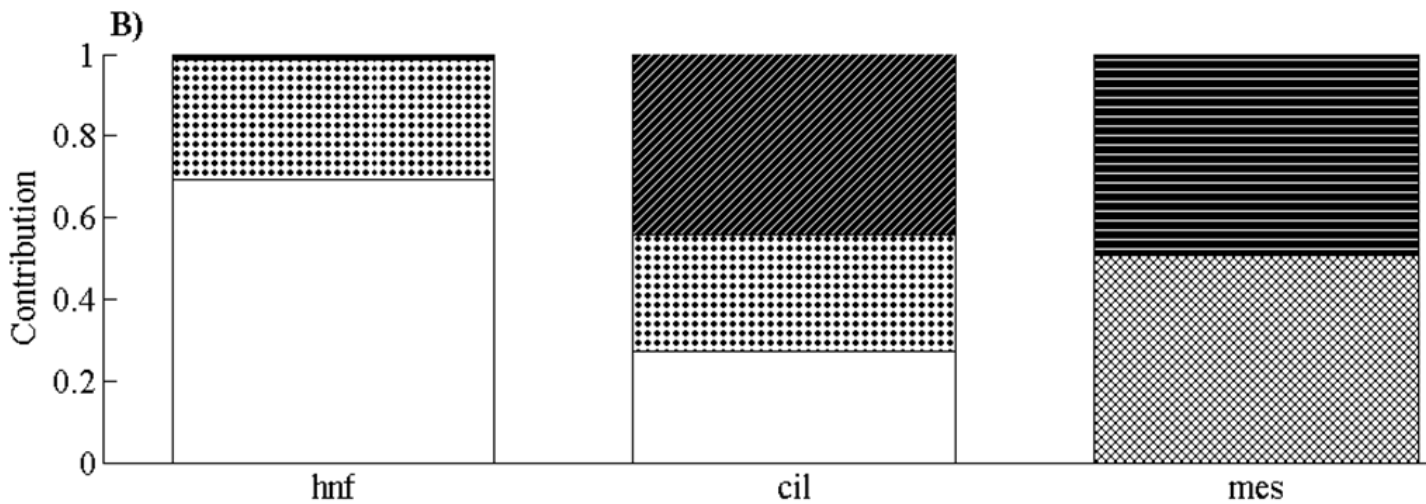

cil

mes

1127 
Figure 5

TST

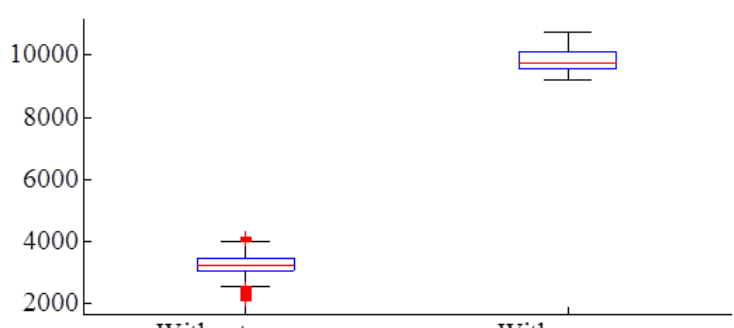

Without resusp.

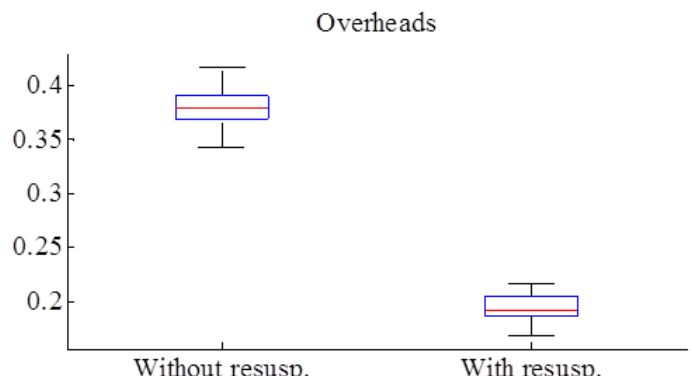

AMI

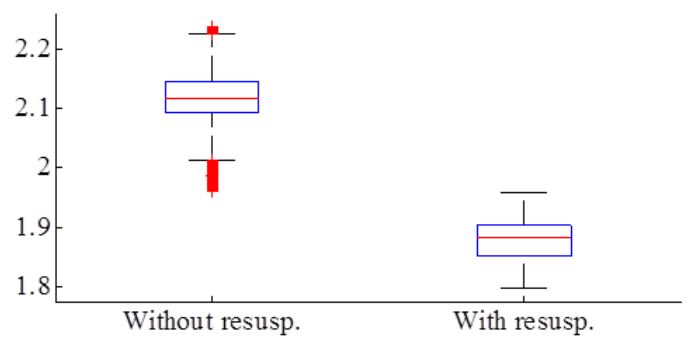

FCI

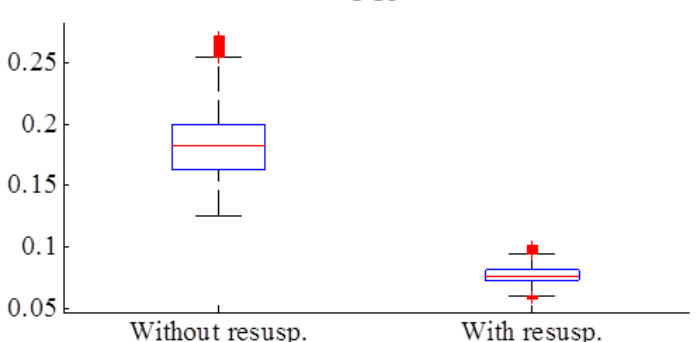

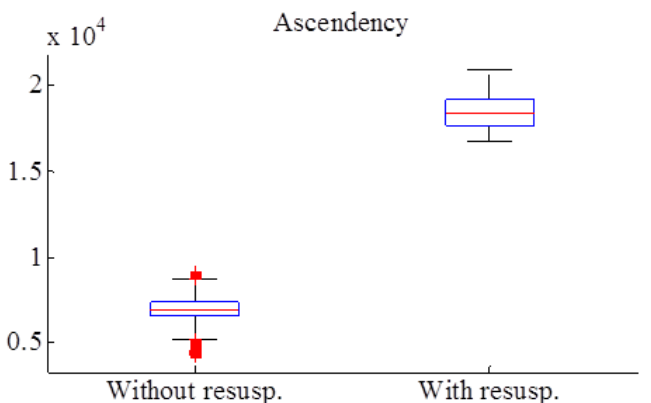

A/DC

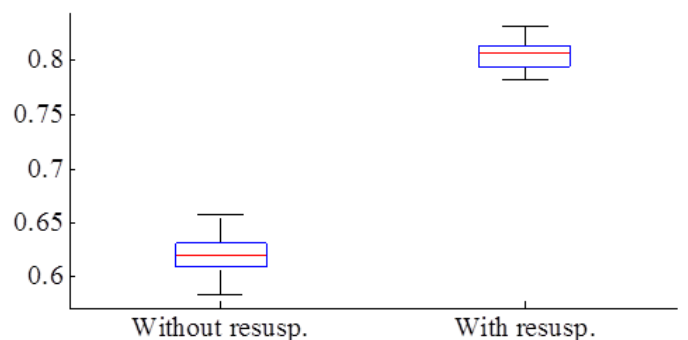

$\mathrm{Ai} / \mathrm{DCi}$

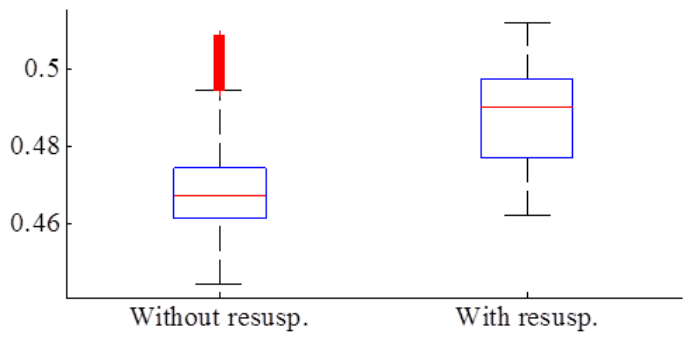

